\title{
EVALUATION OF BMP2/miRNA CO-EXPRESSION SYSTEMS FOR POTENT THERAPEUTIC EFFICACY IN BONE-TISSUE REGENERATION
}

\author{
T.K. Brenner ${ }^{1, \$}$, K. Posa-Markaryan ${ }^{1, \$}$, D. Hercher ${ }^{1,4}$, S. Sperger ${ }^{1,4}$, P. Heimel ${ }^{1,4}$, C. Keibl ${ }^{1}$, S. Nürnberger ${ }^{1,2,3,4}$, \\ J. Grillari ${ }^{1,4,5}, \mathrm{H}$. Red1 ${ }^{1,4}$ and A. Hacobian ${ }^{1,4, *}$ \\ ${ }^{1}$ Ludwig Boltzmann Institute for Experimental and Clinical Traumatology/AUVA Research Centre, \\ The Austrian Cluster for Tissue Regeneration, European Institute of Excellence on Tissue Engineering and \\ Regenerative Medicine Research (Expertissues EEIG), Donaueschingenstrasse 13, 1200 Vienna, Austria \\ ${ }^{2}$ Department of Orthopaedics and Trauma-Surgery, Division of Trauma-Surgery, \\ Medical University of Vienna, Währinger Gürtel 18-20, 1090 Vienna, Austria \\ ${ }^{3}$ University Clinic of Dentistry, Medical University of Vienna, Sensengasse 2a, 1090 Vienna, Austria \\ ${ }^{4}$ Austrian Cluster for Tissue Engineering \\ ${ }^{5}$ Institute for Molecular Biotechnology, Department of Biotechnology, BOKU - University of Natural \\ Resources and Life Sciences, Vienna, Austria \\ $\S$ These authors contributed equally to this work
}

\begin{abstract}
Reconstruction of bone defects and compensation of deficient repair mechanisms represent important goals within the field of regenerative medicine and require novel safe strategies for translation into the clinic. A non-viral osteogenic gene therapeutic vector system ('hybrid vectors') was generated, combining an improved bone morphogenetic protein 2 (BMP2) gene cassette and single pro-osteogenic microRNAs (miR-148b-3p, miR-20-5p, miR-590b-5p), driven by the U6 promoter. The vectors were tested in vitro for their osteogenic differentiation potential in $\mathrm{C} 2 \mathrm{C} 12$ and $\mathrm{C} 3 \mathrm{H} / 10 \mathrm{~T} 1 / 2$ cell lines, using $B M P 2$ alone as a control. After confirming $B M P 2$ expression and miRNA transcription, increased osteogenic differentiation was observed by all hybrid vectors, but most consistently by $B M P 2 / \mathrm{miR}-590-5 \mathrm{p}$, using alkaline phosphatase enzyme activity assays and osteogenic marker mRNA quantitation, including runt-related transcription factor 2 (Runx2), collagen type 1 (Col1a1) and osteocalcin. To visualise target mRNAs of the respective miRNAs, next generation sequencing was performed, confirming down-regulation of mRNA targets of the hybrid vectors. Since the hybrid vector consisting of BMP2 and miR-590-5p showed the largest increase in osteogenic differentiation in vitro, this was tested in a mouse ectopic-bone model. Mineralisation was more than with BMP2 alone.

The present study showed hybrid vectors as a novel non-viral gene therapeutic plasmid system for combining therapeutic effects of recombinant protein expression and miRNA transcription that did not add to the burden of the translation machinery, while improving the therapeutic efficacies. In vivo proof-ofprinciple in the context of bone regeneration suggested that such hybrid vectors will be applicable in a wide array of gene therapeutic strategies.
\end{abstract}

Keywords: Gene therapy, bone morphogenetic protein 2, microRNA-590, microRNA-148b, microRNA-20a, microRNA, ectopic bone, hybrid vector.

*Address for correspondence: Ara Hacobian, Donaueschingenstrasse 13, 1200 Vienna, Austria.

Telephone number: +436801348411 Email: a.hacobian@gmx.net

Copyright policy: This article is distributed in accordance with Creative Commons Attribution Licence (http://creativecommons.org/licenses/by-sa/4.0/).

\begin{tabular}{|c|c|c|c|}
\hline & List of Abbreviations & BAMBI & $\begin{array}{l}\text { BMP and activin membrane bound } \\
\text { inhibitor }\end{array}$ \\
\hline ACTR5 & actin-related protein 5 & BMP2 & bone morphogenetic protein 2 \\
\hline Alk-2 & activin receptor-like kinase-2 & BMPR2 & BMP receptor 2 \\
\hline ALP & alkaline phosphatase & cDNA & complementary DNA \\
\hline ALPL & liver/bone/kidney alkaline & COL1A1 & collagen type 1 \\
\hline APC & $\begin{array}{l}\text { phosphatase } \\
\text { anaphase-promoting complex }\end{array}$ & CRIM1 & $\begin{array}{l}\text { cysteine-rich transmembrane BMP } \\
\text { regulator } 1\end{array}$ \\
\hline
\end{tabular}




\begin{tabular}{|c|c|}
\hline$\Delta \mathrm{CT}$ & delta threshold cycle \\
\hline DMEM & Dulbecco's modified Eagle's medium \\
\hline $\mathrm{EF} 1 \alpha$ & translation elongation factor 1 alpha \\
\hline ELISA & enzyme-linked immunosorbent \\
\hline & $\begin{array}{l}\text { assay } \\
\text { foetal calf serum }\end{array}$ \\
\hline FCS & toetal calt serum \\
\hline FGF & fibroblast growth factor \\
\hline FOP & fibrodysplasia ossificans progressiva \\
\hline hASCs & $\begin{array}{l}\text { human adipose-tissue-derived } \\
\text { stromal cells }\end{array}$ \\
\hline $\mathrm{HE}$ & haematoxylin and eosin \\
\hline hMSCs & human mesenchymal stem cells \\
\hline HPRT & $\begin{array}{l}\text { hypoxanthine-guanine } \\
\text { phosphoribosyl transferase }\end{array}$ \\
\hline hsa-miR & homo sapiens microRNA \\
\hline$\mu \mathrm{CT}$ & micro-computed tomography \\
\hline MetLuc & Metridia longa luciferase \\
\hline miRNA & microRNA \\
\hline mRNA & messenger RNA \\
\hline MSCs & mesenchymal stem cells \\
\hline NGS & next generation sequencing \\
\hline OCN & osteocalcin \\
\hline PPARG & $\begin{array}{l}\text { peroxisome-proliferator-activated } \\
\text { receptor } \gamma\end{array}$ \\
\hline rhBMP2 & recombinant human $\mathrm{BMP} 2$ protein \\
\hline rRNA & ribosomal RNA \\
\hline ROCK1 & $\begin{array}{l}\text { rho-associated coiled-coil containing } \\
\text { protein kinase } 1\end{array}$ \\
\hline ROI & region of interest \\
\hline RT-qPCR & $\begin{array}{l}\text { reverse transcription quantitative } \\
\text { polymerase chain reaction }\end{array}$ \\
\hline RUNX2 & runt-related transcription factor 2 \\
\hline SD & standard deviation \\
\hline shRNA & short hairpin RNA \\
\hline siRNA & short interfering RNA \\
\hline SMAD7 & SMAD family member 7 \\
\hline snRNA & small nuclear RNA \\
\hline TGF $\beta$ & transforming growth factor $\beta$ \\
\hline TGFBR2 & TGF $\beta$ receptor 2 \\
\hline WNT3A & Wnt family member 3A \\
\hline
\end{tabular}

\section{Introduction}

Reconstruction of bone defects and compensation for deficient repair mechanisms represent important goals within the field of regenerative medicine. Large bone regeneration is required in complex clinical conditions, such as reconstruction of large bonedefects caused by trauma, infection and tumour resection, or cases in which the regenerative process is compromised, including non-union bone defects and osteoporosis (Audigé et al., 2005; Dimitriou et al., 2011). Current strategies for stimulating bone growth range from application of recombinant protein to viral as well as non-viral gene therapeutic approaches (Bleiziffer et al., 2007; Feichtinger et al., 2014a; Kempen et al., 2010; Koh et al., 2008; Sood et al., 2012; Southwood et al., 2004). Due to transient expression profiles and clinical safety, non-viral plasmids represent a suitable strategy for clinical translation within tissue regenerative gene therapy (Bleiziffer et al., 2007; Glover et al., 2005).

An improved osteogenic vector system encoding BMP2 was recently introduced (Hacobian et al., 2016). The main bottle-neck of non-viral gene therapy - low target-gene expression - was compensated for by use of a strong promoter, codon optimisation and insertion of an artificial largely truncated intron sequence, resulting in an improved therapeutic BMP2 vector (BMP2-Advanced, in the following referred to as $\mathrm{pBMP2}{ }_{\mathrm{ADV}}$ ) (Hacobian et al., 2016). Aside from the need to increase therapeutic protein production, further improvement of therapeutic vector bio-efficacy, such as the simultaneous knockdown of transgene inhibitors, is considered to support successful translation of non-viral vectors to the clinic (Al-Dosari and Gao, 2009; Kay, 2011; Mingozzi and High, 2011; Wang et al., 2013). Recently, the application of miRNAs in tissue regeneration has attracted much interest (Peng et al., 2015). At the same time, scientific knowledge of the involvement of miRNAs throughout the osteogenic differentiation cascade (Lian et al., 2012; Zhai et al., 2017) and in bone formation and osteoporosis (et al., 2015a) has increased. In general, miRNA-function can be divided into two categories depending on the degree of sequence complementarity: specific downregulation of target mRNA transcription and/or translation. One mRNA can be regulated by multiple miRNAs just as a single miRNA can recognise a multitude of different targets at once (Lim et al., 2005). Utilisation of miRNAs for in vivo bone tissue engineering has recently emerged to specifically enhance or suppress differentiation and target-gene expression (Deng et al., 2014; Eskildsen et al., 2011; Li et al., 2017; Liao et al., 2014). Therefore, a combinatorial approach of miRNA-dependent gene regulation and overexpression of a therapeutic gene encoded by a single-plasmid-system (hybrid vector) has the potential to increase biological efficacy of therapeutic plasmids and drive cellular fate in a desired direction.

Following a literature search, multiple miRNAs potentially involved in the osteogenic pathway were selected for integration into the non-viral $\mathrm{pBMP} 2_{\mathrm{ADV}}$ vector. In preliminary tests (data not shown), the selection was reduced to the three most potent candidates, human miR-148b-3p, hsa-miR-590-5p and hsa-miR-20a-5p. These miRNAs were individually incorporated into $\mathrm{pBMP} 2_{\mathrm{ADV}}$, under the control of a human U6 promoter, a well-studied competent RNA polymerase III promoter that constitutively transcribes small RNAs (Duvoisin et al., 2012). Combination of these elements resulted in the generation the hybrid plasmids. Then, these plasmids were tested for their osteoinductive potential, in vitro as well as in vivo, using an ectopic-bone mouse model. The study hypothesis was that these newly designed miRNA-BMP2 co-expression constructs possessed a 
greater osteoinductive potency than the previously introduced BMP2 overexpression plasmid (Hacobian et al., 2016).

\section{Materials and Methods}

\section{Plasmid construction}

The $B M P 2_{A D V}-$ Hybrid vectors (Fig. 1a) include a codon-optimised human BMP2 sequence (Gene ID: 650) with an implemented intron, as previously described (Hacobian et al., 2016). The original EF1 $\alpha$ $\mathrm{BMP} 2-\mathrm{Adv}$ vector, in the following called $\mathrm{pBMP} 2_{\mathrm{ADV}}$ was modified by incorporating a selection of shRNA sequences (Table 1) into the variable cloning site in forward direction respect to the EF- $1 \alpha$ promoter, as this facilitated stronger target gene knockdown (Fig. 1b). A U6 RNA polymerase III promoter was inserted upstream of the shRNAs.
A schematic illustration of control plasmid pHybrid_MetLuc, specifically designed to investigate miRNA influence on differentiation processes uncoupled from $B M P 2_{A D V}$ expression, is also depicted in Fig. 1a. $B M P 2_{A D V}$ was replaced by secreted MetLuc gene.

To investigate successful knockdown of a reporter gene via the incorporated shRNA/U6 promoter system, an artificial hairpin structure (anti-Luc) was expressed, targeted against a click-beetle luciferase gene, co-expressed from a pGL3 plasmid (Promega).

\section{Cell culture and reagents}

C3H/10T1/2 (ATCC CCL-226) mouse embryonic cells and Chinese hamster ovary (CHO-K1) cell line (ATCC CCL-61) were cultured in DMEM (Sigma-Aldrich) high glucose $(4.5 \mathrm{~g} / \mathrm{L}$ glucose), supplemented with $2 \mathrm{mmol} / \mathrm{L}$ L-glutamine (Sigma-Aldrich) and $10 \%$ FCS (Sigma-Aldrich). C2C12 mouse muscle myoblast
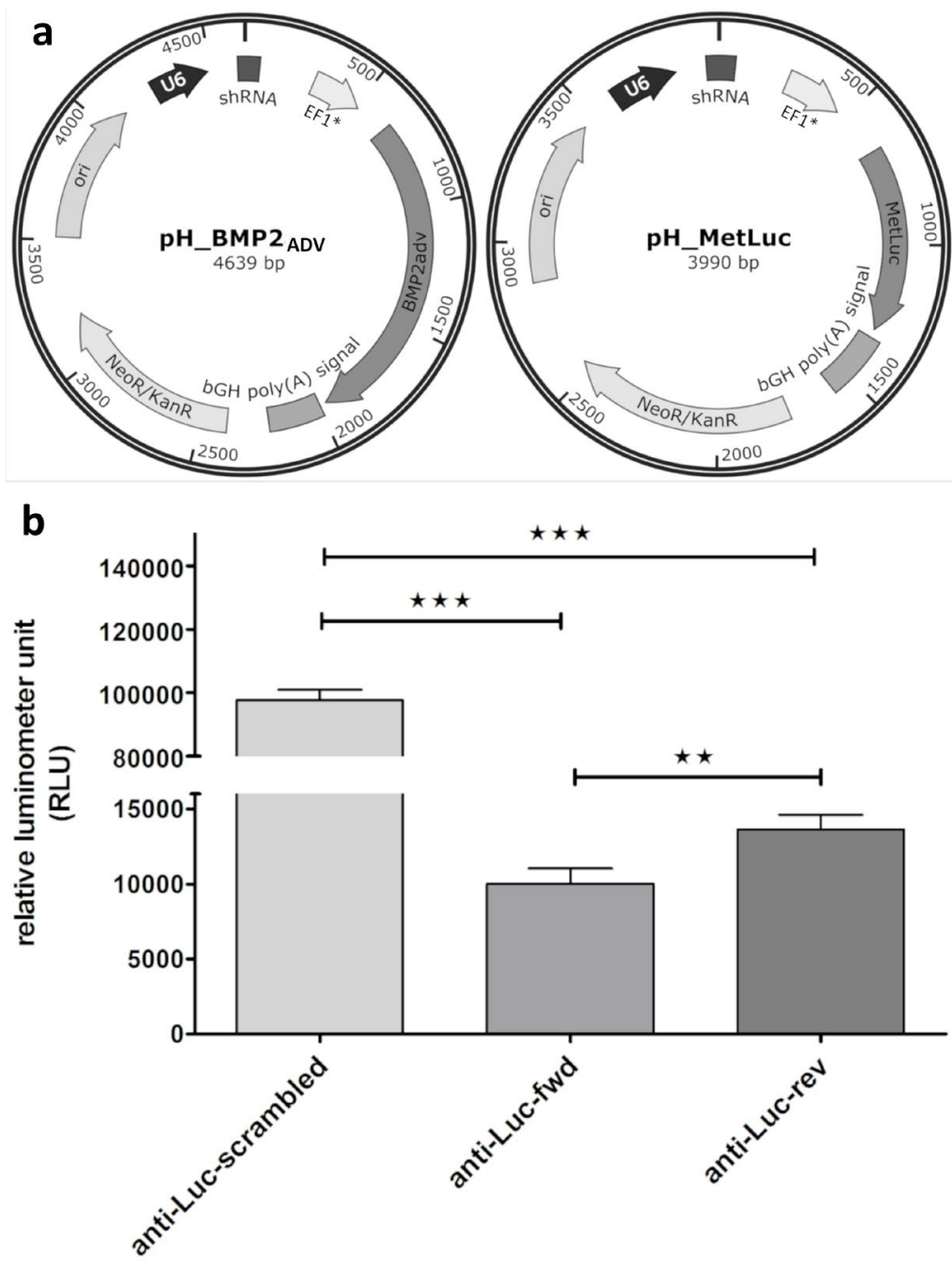

Fig. 1. Plasmid maps and reporter gene knockdown. (a) Schematic representation of the Hybrid vector system. U6 RNA III promoter controls shRNA expression. Downstream transcription of a gene of interest, here $\mathrm{BMP}_{\mathrm{ADV}}$ or Metridia longa luciferase, is regulated via a minimal EF1 $\alpha$ promoter sequence. Res, antibiotic resistance selection marker; ori, origin of bacterial replication. Plasmid map was designed with SnapGene Viewer software (from GSL Biotech; available at www.snapgene.com). (b) Reporter luciferase gene knockdown. Luciferase activity $2 \mathrm{~d}$ after transfection of $\mathrm{C} 3 \mathrm{H} / 10 \mathrm{~T} 1 / 2$ cells. Both anti-Luc hairpin orientations showed successful reduction in target protein. However, forward orientation suppressed luciferase production more efficiently. Averaged data are presented as means $\pm \mathrm{SD}, n=8$. Statistical differences were determined by one-way ANOVA followed by Tukey post-hoc test analysis. 
Table 1. List of plasmids constructed and used.

\begin{tabular}{|c|c|c|c|}
\hline Plasmid name & $\begin{array}{l}\text { Encoded } \\
\text { miRNA }\end{array}$ & $\begin{array}{c}\text { NCBI } \\
\text { accession } \\
\text { number }\end{array}$ & shRNA sequence $\left(5^{\prime}-3^{\prime}\right)$ \\
\hline $\mathrm{pH} \_\mathrm{BMP} 2_{\mathrm{ADV}} 148 \mathrm{~b}$ & hsa-miR-148b & NR_029894.1 & $\begin{array}{l}\text { CAAGCACGATTAGCATTTGAGGTGAAGTTCTGTTATACACTCAGGCTGTG- } \\
\text { GCTCTCTGAAAGTCAGTGCATCACAGAACTTTGTCTCGAAAGCTTTCTA }\end{array}$ \\
\hline pH_BMP2 ${ }_{\mathrm{ADV}} 590$ & hsa-miR-590 & NR_030321.1 & $\begin{array}{l}\text { TAGCCAGTCAGAAATGAGCTTATTCATAAAAGTGCAGTATGGTGAAGT- } \\
\text { CAATCTGTAATTTTATGTATAAGCTAGTCTCTGATTGAAACATGCAGCA }\end{array}$ \\
\hline pH_BMP2 ${ }_{\mathrm{ADV}} 20 \mathrm{a}$ & hsa-miR-20a & NR_029492.1 & $\begin{array}{l}\text { GTAGCACTAAAGTGCTTATAGTGCAGGTAGTGTTTAGTTATCTACTGCAT- } \\
\text { TATGAGCACTTAAAGTACTGC }\end{array}$ \\
\hline pH_BMP2 ${ }_{\mathrm{ADV}} \mathrm{scr}$ & anti-Luc-fwd & $\mathrm{n} / \mathrm{a}$ & CCCCgactaaactgagcgtccagttTCAAGAGaactggacgctcagtttagtcTTTT \\
\hline
\end{tabular}

Table 2. Primer sequences used for RT-qPCR analysis.

\begin{tabular}{|c|c|c|c|c|c|}
\hline $\begin{array}{c}\text { Target } \\
\text { mRNA }\end{array}$ & $\begin{array}{c}\text { NCBI accession } \\
\text { number }\end{array}$ & Forward primer $\left(5^{\prime}\right.$-3') & Reverse primer $\left(5^{\prime}\right.$-3') & $\begin{array}{c}\text { Amplicon } \\
\text { length }\end{array}$ & $\begin{array}{c}\text { Annealing } \\
\text { temperature }\end{array}$ \\
\hline BMP2 $_{\text {ADV }}$ & n/a & GAGCAGATGCAGGATGC & TCCATCTCATCACGGCA & $187 \mathrm{bp}$ & $61{ }^{\circ} \mathrm{C}$ \\
\hline HPRT & NM_013556.2 & AGTCCCAGCGTCGTGATTAG & TGGCCTCCCATCTCCTTCAT & $167 \mathrm{bp}$ & $63.5^{\circ} \mathrm{C}$ \\
\hline GAPDH & XM_017321385.1 & CTGAGTATGTCGTGGAGTC & GGATGCATTGCTGACAATC & $179 \mathrm{bp}$ & $55^{\circ} \mathrm{C}$ \\
\hline ACTR5 & XM_016964770 & TGCTGGATGCCTGGTATGG & ACCCAGGCTCCACTGTCTTCT & $67 \mathrm{bp}$ & $62^{\circ} \mathrm{C}$ \\
\hline ALPL & XM_006538497 & GCACCTGCCTTACCAACTCTT & GGCTACATTGGTGTTGAGCTTTT & $122 \mathrm{bp}$ & $61{ }^{\circ} \mathrm{C}$ \\
\hline COL1A1 & XM_021213774 & CAGCCGCAAAGAGTCTACATG & GGTTTCCACGTCTCACCATTG & $172 \mathrm{bp}$ & $61{ }^{\circ} \mathrm{C}$ \\
\hline OCN & NM_007541.3 & GAACAGACAAGTCCCACACAG & CTGCTTGGACATGAAGGCTTT & $448 \mathrm{bp}$ & $60{ }^{\circ} \mathrm{C}$ \\
\hline RUNX2 & XM_006523540.2 & CAAGTAGCCAGGTTCAACGA & CTGAGGCGATCAGAGAACAA & $209 \mathrm{bp}$ & $58^{\circ} \mathrm{C}$ \\
\hline
\end{tabular}

precursor cell line (DSMZ, Braunschweig, Germany, \#ACC565) was cultivated under the same conditions except for a reduced serum concentration of $5 \%$.

\section{In vitro transfection}

Cells were seeded $24 \mathrm{~h}$ before transfection into 24- or 48-well cell culture plates at a cell density of $0.25 \times 10^{5} / \mathrm{cm}^{2}(\mathrm{C} 3 \mathrm{H} / 10 \mathrm{~T} 1 / 2), 0.3 \times 10^{5} / \mathrm{cm}^{2}$ (C2C12) or $0.4 \times 10^{5} / \mathrm{cm}^{2}(\mathrm{CHO}-\mathrm{K} 1)$. According to the manufacturer's instructions, endotoxin-free plasmids were incubated with transfection reagent (Turbofect, Peqlab Biotechnologie $\mathrm{GmbH}$, Erlangen, Germany) in serum-free medium for $15 \mathrm{~min}$. Target cells were transfected at 80 to $90 \%$ confluency with $1 \mu \mathrm{g}$ of indicated plasmid/mL medium using $2 \mu \mathrm{L}$ transfection reagent. $6 \mathrm{~h}$ post transfection, medium was changed. Transfection efficiencies were approximated for each cell line using parallel control transfections with GFP-expression plasmids (data not shown). Transfection efficiency was accepted when a level of approximately $\geq 80 \%$ was reached. No statistical comparison between cell lines was performed. Therefore, possible differences in transfection efficiency were not considered relevant.

\section{ALP assay}

Transfected cells were lysed for $1 \mathrm{~h}$ at room temperature using $100 \mu \mathrm{L}$ lysis buffer consisting of ALP buffer [0.5 mol/L 2-amino-2-methyl-1-propanol (Sigma-Aldrich, \#A9199), $2 \mathrm{mmol} / \mathrm{L}$ magnesium chloride (Sigma-Aldrich, \#M8266, pH 10.3), $0.5 \%$ Triton X-100 (Sigma-Aldrich, \#93443)]. Enzymatic activity was induced by addition of substrate solution, consisting of $20 \mathrm{mmol} / \mathrm{L} \mathrm{p}$-nitrophenylphosphate
(Sigma-Aldrich, \#71768) in $50 \mu \mathrm{L}$ ALP buffer. After $20 \mathrm{~min}$, the reaction was stopped using $50 \mu \mathrm{L}$ of $0.2 \mathrm{~mol} / \mathrm{L} \mathrm{NaOH}$ (Sigma-Aldrich, \#71689). Conversion of p-nitrophenylphosphate to p-nitrophenol by ALP was measured at $405 \mathrm{~nm}$ using a Polarstar Omega plate reader (BMG Labtech, Ortenberg, Germany). Due to distinct differentiation kinetics, ALP activity was measured 3 (C2C12) and $6 \mathrm{~d}(\mathrm{C} 3 \mathrm{H} / 10 \mathrm{~T} 1 / 2)$ after transfection, respectively. A single treatment with $150 \mathrm{ng} / \mu \mathrm{L}$ rhBMP2 was used as a positive osteogenicdifferentiation control.

\section{Luciferase assay}

Luciferase activity was quantified according to the Renilla Luciferase Assay System (Promega Corporation, \#E2810) standard protocol.

\section{ELISA}

Quantification of secreted BMP2 levels was carried out using the DuoSet ELISA Development kit (R\&D Systems, \#DY335) for human BMP2, according to the manufacturer's instructions. Absorbance was measured at $450 \mathrm{~nm}$ using a Polarstar Omega plate reader (BMG Labtech), with wavelength correction at $570 \mathrm{~nm}$. ELISA was performed 2 and $4 \mathrm{~d}$ (CHO-K1) as well as 3 and $6 \mathrm{~d}(\mathrm{C} 2 \mathrm{C} 12, \mathrm{C} 3 \mathrm{H} / 10 \mathrm{~T} 1 / 2)$ after transfection. $100 \mu \mathrm{L}$ cell culture supernatants were collected at stated time points and cells were incubated in remaining medium up to the last sampling day.

\section{RT-qPCR}

Cells were harvested and total RNA was extracted using TriFast reagent (Peqlab, Biotechnologie 
$\mathrm{GmbH}$, \#30-2010). Time points for qPCR analysis were selected specifically for each marker of osteogenesis. RNA concentrations were determined using a NanoDrop One spectrophotometer (Thermo Fisher Scientific). cDNA was synthesised from total RNA $(2 \mu \mathrm{g})$ using an OneScript cDNA Synthesis Kit (abmGood, Richmond, Canada, \#G234). Each PCR reaction consisted of $4 \mu \mathrm{L}$ diluted cDNA (40 ng), $10 \mu \mathrm{L}$ PerfeCTa SYBR Green SuperMix (Quantabio, Beverly, MA, USA, \#733-1247) and specific primer pairs $(250 \mathrm{nmol} / \mathrm{L})$ in a total volume of $20 \mu \mathrm{L}$. Reaction volume was collected in a colourless PCR 96-well TW-MT plate (Biozym, Hamburg, Germany, \#712240X) sealed with adhesive clear PCR seal sheets (Biozym, \#600208). Three-step reaction protocols were performed using a C1000/CFX96 Thermal Cycler (BioRad). To confirm amplification specificity, the PCR products were subjected to a dissociation curve analysis. Gene expression levels were reported relative to gene expression of reference gene using the $2^{-\Delta \Delta C_{t}}$ method (Schmittgen and Livak, 2008). The reference genes Hprt for C2C12 and C3H/10T1/2 (Masilamani et al., 2014; Rahim et al., 2017) and Actr5 for CHO-K1 (Bahr et al., 2009) were used for normalisation. All primers were synthesised by Microsynth (Balgach, Switzerland). Primer names and sequences used for RT-qPCR are listed in Table 2.

\section{miRNA quantification using RT-qPCR}

Following $\mathrm{C} 3 \mathrm{H} / 10 \mathrm{~T} 1 / 2$ cell transfection with hybrid plasmids, quantification of basal as well as overexpressed cytosolic and secreted miRNAs was conducted by TAmiRNA (Vienna, Austria).

Total RNA was extracted from cell pellets and supernatants using the miRNeasy mini Kit (Qiagen). Samples were thawed on ice and centrifuged at $12,000 \times g$ for $5 \mathrm{~min}$ to remove any cellular debris. For each sample, $200 \mu \mathrm{L}$ of supernatant or cell pellet were homogenised with $1 \mathrm{~mL}$ QIAzol (Qiagen). A mix of three synthetic spike-in controls (Exiqon) was added to QIAzol prior to homogenisation to monitor extraction efficiency and the variance of the analytical procedure. Following incubation at room temperature for $10 \mathrm{~min}, 200 \mu \mathrm{L}$ of chloroform were added to the lysates followed by centrifugation at $12,000 \times g$ for $15 \mathrm{~min}$ at $4{ }^{\circ} \mathrm{C}$. $650 \mu \mathrm{L}$ of the upper aqueous phase were mixed with $7 \mu \mathrm{L}$ glycogen (50 $\mathrm{mg} / \mathrm{mL}$ ) to enhance precipitation. Samples were transferred to a miRNeasy mini column and RNA was precipitated using $750 \mu \mathrm{L}$ ethanol followed by automated washing with RPE and RWT buffer in a QiaCube liquid handling robot. Finally, total RNA was eluted in $30 \mu \mathrm{L}$ nuclease-free water and stored at $-80^{\circ} \mathrm{C}$ until further analysis.

Starting from total RNA samples, cDNA was synthesised using the Universal cDNA Synthesis Kit II (Exiqon). Reaction conditions were set according to recommendations by the manufacturer. For total RNA extracted from supernatants, $2 \mu \mathrm{L}$ of total RNA were used per $10 \mu \mathrm{L}$ reverse transcription reaction, since RNA concentrations were below the limit of detection. In contrast, $10 \mathrm{ng}$ total RNA from cell pellets were applied for reverse transcription. PCR amplification was performed in a 96-well plate using a Roche LC480 II instrument and EXiLENT SYBR Green master mix (Exiqon), with the following settings: $95^{\circ} \mathrm{C}$ for $10 \mathrm{~min}, 45$ cycles of $95^{\circ} \mathrm{C}$ for $10 \mathrm{~s}$ and $60^{\circ} \mathrm{C}$ for $60 \mathrm{~s}$, followed by melting curve analysis. The second derivative maximum method was used to calculate the cycle of quantification values (Ctvalues).

In case of supernatants, the raw Ct-values were normalised to the RNA spike-in control level, by subtracting the individual miRNA Ct-value from the individual RNA Spike-In Ct, thus obtaining delta $\mathrm{Ct}$ $(\triangle \mathrm{Ct})$ values that were used for the analysis. In case of cell pellets, U6 snRNA and 5S rRNA (assays derived from Exiqon) of each sample were used for individual normalisation using the same procedure.

\section{NGS}

Total RNA from C3H/10T1/2 cell lysate was collected $3 \mathrm{~d}$ after transfection. mRNA libraries were generated from $100 \mathrm{ng}$ total RNA input using Quant Seq 3'mRNA Library Prep KitFWD for Illumina (Lexogen, Austria) according to the manufacturer's instructions. Libraries were amplified for 16 cycles using barcoded Illumina reverse primer (i7 index primer) in combination with Illumina forward primer. Fragment size and quantity was assessed using the Bioanalyzer DNA High Sensitivity Chip (Agilent). An equimolar pool was generated from the individual libraries and sequenced on an Illumina Hiseq2500 with $100 \mathrm{bp}$ single-end reads.

\section{NGS data analysis}

Reads obtained by NGS were analysed using the integrated Data Analysis Pipeline on the Bluebee ${ }^{\circledR}$ platform. This pipeline uses fastQC (v0.11.5) (Web ref. 1) for overall sequencing quality assessment and bbduk (v35.92) to trim adapters and polyA tails. Reads are aligned with the STAR aligner (v2.5.2a) (Dobin et al., 2013) and gene reads counted using HTSeq-count (v0.6.0) (Anders et al., 2015). Differential expression analysis is performed with DESeq2 (v3.11) (Love et al., 2014) following best practice guidelines from the package's description. Validated miRNAtargets for mmu-miR-20a-5p, mmu-miR-148b-3p and mmu-miR-590-5p were obtained from TarBase (Karagkouni et al., 2018). As the seed sequences of mmu-miR-590-5p and mmu-miR-21-5p are identical, the latter's targets were also included.

\section{In vivo transfection}

Eight female CD- $1^{\circledR}$ mice [Charles River, Crl:CD1 (ICR)], 14 weeks old and weighing approximately $30 \mathrm{~g}$ were used in the ectopic-bone model. Mouse analgesia was performed using Meloxicam $(0.1 \mathrm{mg} /$ $\mathrm{kg}$, Boehringer Ingelheim). Prior to transfection, mice were placed under inhalation anaesthesia with isoflurane 1 to 3 volume \% (Forane, AbbVie, Vienna, Austria) and $3 \mathrm{~L} / \mathrm{min}$ air. $30 \mu \mathrm{g}$ of plasmid DNA was 
first incubated for $20 \mathrm{~min}$ at room temperature with In vivo PolyMag ${ }^{\mathrm{TM}}$ Transfection Reagent (OzBiosciences, Marseille, France, \#IV-PN31000) at a $1: 2$ ratio for complex formation in a total volume of $100 \mu \mathrm{L}$. Subsequently, complexed DNA was injected in a single-shot manner into the centre of the musculus gastrocnemius at the hind limb using a $27 \mathrm{G}$ needle. Magnets $(17 \times 17 \times 5 \mathrm{~mm})$ were applied at the site of transfection for $30 \mathrm{~min}$ to facilitate gene delivery. Animal experiments were approved by the City Government of Vienna, Austria and were conducted in accordance with the Guide for the Care and Use of Laboratory Animals as defined by the National Institute of Health (TVA-No.: 1755694/2014/11).

\section{$\mu \mathrm{CT}$}

All 16 hind limbs were scanned 8 weeks after transfection and hind limb harvested using a SCANCO $\mu$ CT 50 (SCANCO AG) at 70 kVp, $200 \mu \mathrm{A}$ with an integration time of $500 \mathrm{~ms}$. The resulting resolution was $10 \mu \mathrm{m}$ isotropic. Calcification volumes were measured using ImageJ 1.51h, Fiji (Eliceiri et al., 2012; Schindelin et al., 2012). A ROI that included all visible ectopic calcifications was drawn using the ROI Manager. A minimal gap of $150 \mu \mathrm{m}$ was kept between the entopic bone and the ROI. Scans were medianfiltered using the 3D median filter with a radius of 3 pixels. The volume of all structures inside the ROI above a threshold of $100 \mathrm{mgHA} / \mathrm{cm}^{3}$ was measured.

\section{Histological analysis}

After an 8-week observation period, all mice were euthanised by cervical dislocation under inhalation anaesthesia using isoflurane 5 volume \% (Forane, AbbVie) and $3 \mathrm{~L} / \mathrm{min}$ air. Hind limbs were removed as proximally as possible, fixed for $48 \mathrm{~h}$ in $4 \%$ formaldehyde solution, rinsed in tap water, transferred to $50 \%$ ethanol for slow dehydration of samples and stored in $70 \%$ ethanol at $4{ }^{\circ} \mathrm{C}$. Musculus gastrocnemius was excised and embedded in paraffinwax using a Tissue-Tek VIP (Sakura Finetek Europe, Alphen aan den Rijn, the Netherlands). Multiple sections of each sample were stained with $\mathrm{HE}$, as well as von Kossa and collagen type 2 (NeoMarkers, Freemont, CA, USA, MS-306-P1) for detection of mineralisation, according to standard histological protocols. Samples were processed using a Microm HM 355 s microtome (Thermo Fisher Scientific) to $3 \mu \mathrm{m}$ slices for HE staining and $4 \mu \mathrm{m}$ slices for von Kossa and collagen type 2 staining.

\section{Statistical analysis}

Averaged data are presented as mean \pm SD. Data sets were tested for Gaussian distribution using Kolmogorov-Smirnov test (with Dallal-WilkinsonLillie for $p$ value). Subsequent comparison between multiple data groups was performed by one-way ANOVA followed by Tukey or Dunnett post-hoc test analysis. All statistical analyses were performed using GraphPad Prism 5 software. Differences were considered statistically significant at ${ }^{*} p<0.05$, ${ }^{* *} p<0.01,{ }^{* * *} p<0.001$.

\section{Results}

Forward orientation of a miRNA-expression cassette was optimised for knockdown of luciferase target example

To validate the most efficient orientation of the miRNA expression cassettes, shRNA expression system plasmids harbouring a shRNA targeting click-beetle luciferase gene, co-expressed from a pGL3 plasmid, were transiently introduced into $\mathrm{C} 3 \mathrm{H} / 10 \mathrm{~T} 1 / 2$ cells.
$\mathrm{C} 2 \mathrm{C} 12$

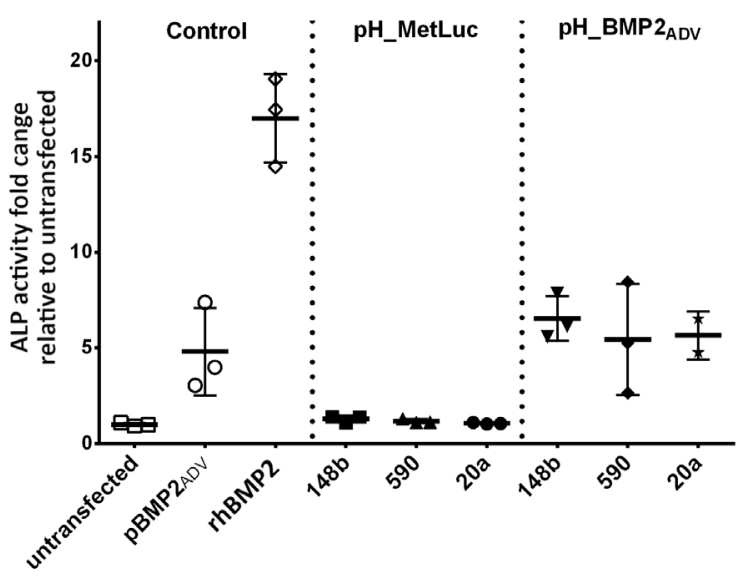

$\mathrm{C} 3 \mathrm{H} / 10 \mathrm{~T} 1 / 2$

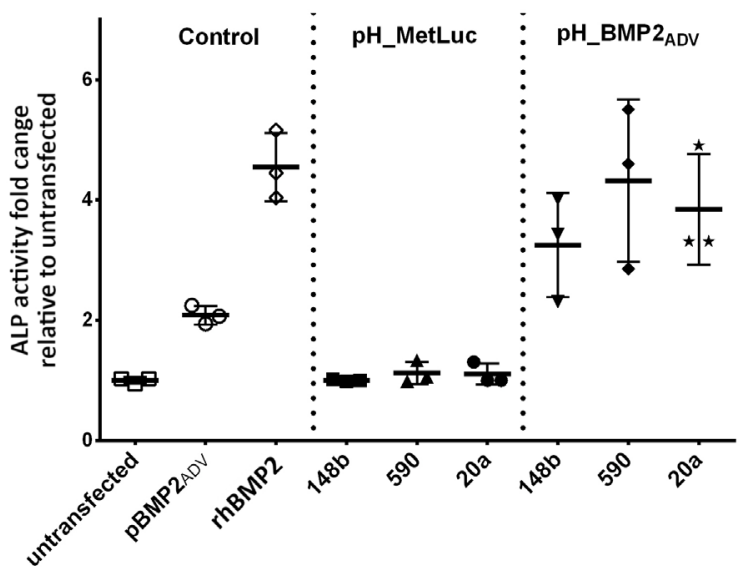

Fig. 2. ALP activity assay. ALP enzyme activity in C2C12 and C3H/10T1/2 cells after transfection. $\mathrm{pH}$ MetLuc control plasmids encoding for Metridia longa luciferase and miRNAs, namely pH_MetLuc148b, $\mathrm{pH} \_$MetLuc590 and $\mathrm{pH} \_$MetLuc20a. $\mathrm{pBMP} 2_{\mathrm{ADV}} \mathrm{pH}_{-} \mathrm{BMP} 2_{\mathrm{ADV}} 148 \mathrm{~b}, \mathrm{pH}$ _BMP2 ${ }_{\mathrm{ADV}} 590$ and $\mathrm{pH}$ _BMP2 ${ }_{\mathrm{ADV}} 20 \mathrm{a}$ were analysed relative to untransfected control. $150 \mathrm{ng} / \mathrm{mL}$ rhBMP2 was used as a positive control. Quantification of ALP activity was measured 3 (C2C12) and $6 \mathrm{~d}(\mathrm{C} 3 \mathrm{H} / 10 \mathrm{~T} 1 / 2)$ after transfection. Averaged data are presented as means $\pm \mathrm{SD}, n=3$. 

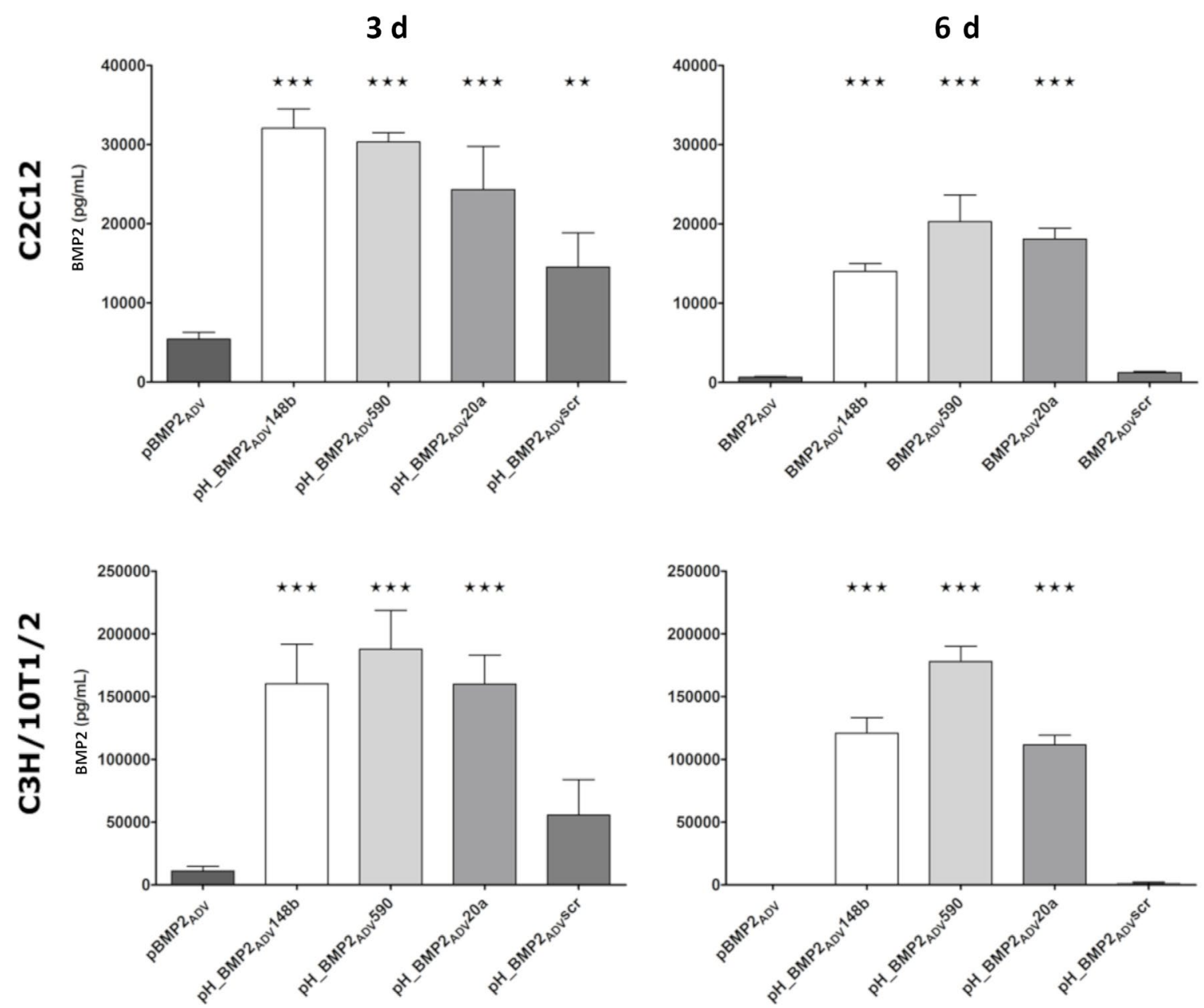

Fig. 3. Secreted BMP2 protein levels by $\mathrm{C} 2 \mathrm{C} 12$ and $\mathrm{C} 3 \mathrm{H} / 10 \mathrm{~T} 1 / 2$ determined by ELISA in cell supernatants after transfection with $\mathrm{pH} \_\mathrm{BMP2}{ }_{\mathrm{ADV}} 148 \mathrm{~b}, \mathrm{pH} \_\mathrm{BMP2}{ }_{\mathrm{ADV}} 590, \mathrm{pH} \_\mathrm{BMP2}{ }_{\mathrm{ADV}} 20 \mathrm{a}, \mathrm{pH} \_\mathrm{BMP2}{ }_{\mathrm{ADV}} \mathrm{scr}$ or $\mathrm{pBMP2}{ }_{\mathrm{ADV}}$ plasmids. Supernatants were sampled 3 and $6 \mathrm{~d}$ after transfection. Averaged data are presented as means $\pm \mathrm{SD}, 3 \mathrm{~d} n=4,6 \mathrm{~d} n=3$. Statistical differences were determined by one-way ANOVA followed by Tukey post-hoc test analysis, comparing all groups with control group $\mathrm{pBMP} 2_{\mathrm{ADV}}{ }^{*}$
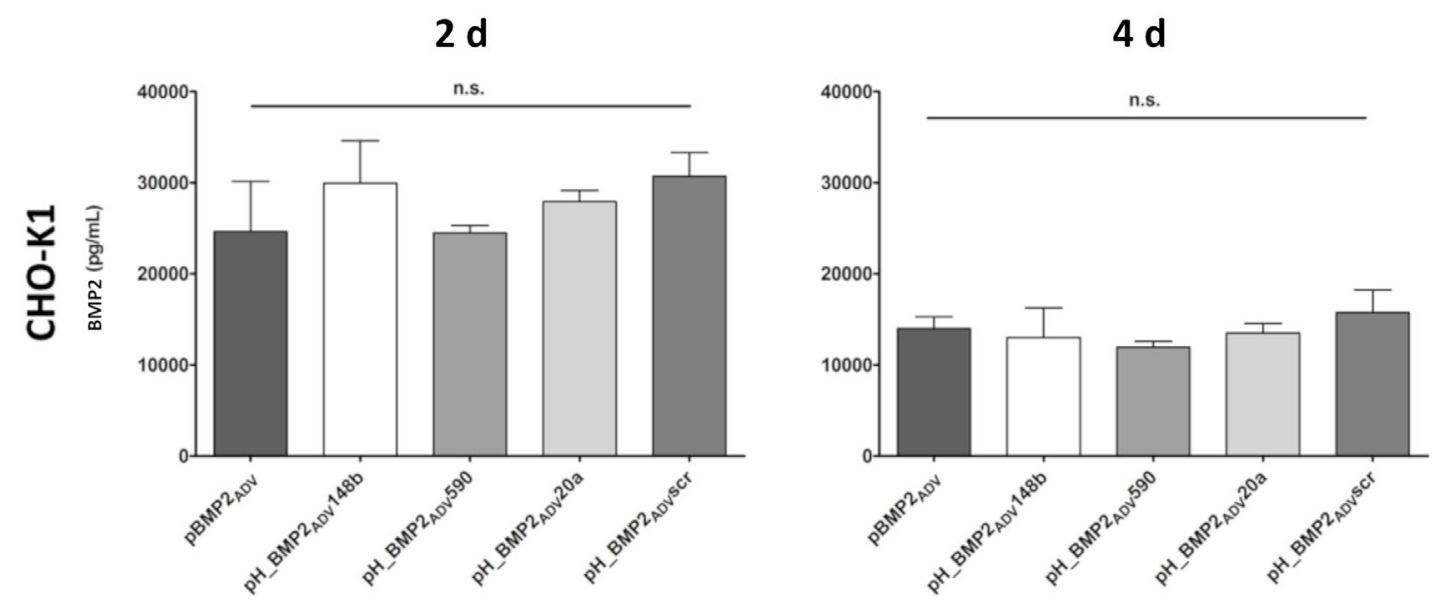

Fig. 4. Secreted BMP2 protein levels in CHO-K1 cells; determined by ELISA. Cells were transfected with $\mathrm{pH}_{-} \mathrm{BMP} 2_{\mathrm{ADV}} 148 \mathrm{~b}, \mathrm{pH} \_\mathrm{BMP} 2_{\mathrm{ADV}} 590, \mathrm{pH} \mathrm{BMP}_{\mathrm{ADV}} 20 \mathrm{a}, \mathrm{pH} \mathrm{BMP}_{\mathrm{ADV}} \mathrm{SCr}$ or $\mathrm{pBMP} 2_{\mathrm{ADV}}$. Cell supernatants were sampled 2 and $4 \mathrm{~d}$ after transfection. Data are represented as means $\pm \mathrm{SD}, n=3$. Statistical differences were determined by one-way ANOVA followed by Tukey post-hoc test analysis. 
shRNA was expressed either in sense (convergent) or antisense (divergent) orientation in respect to the EF-1 $\alpha$-promoter-controlled luciferase expression module. shRNA efficiency in downregulating luciferase activity was quantified through luciferase assay $2 \mathrm{~d}$ after transfection. Target enzyme activity was significantly reduced when the anti-Luc miRNA was co-expressed in comparison to the control plasmid [containing a missense hairpin structure instead (scrambled)]. In addition, convergent coexpression of the anti-Luc hairpin (anti-Luc-fwd) resulted in significantly stronger downregulation of target luciferase than divergent co-expression (antiLuc-rev) (Fig. 1b). Based on these data, a consecutive expression design was adopted for the subsequent construction of the osteogenic hybrid plasmids.

miRNAs alone were not able to induce osteogenic differentiation in target cells

To compare the osteogenic potency of miRNAs alone or co-expressed with $B M P 2$, a control hybrid vector system, pH_MetLuc, was constructed expressing osteogenic miRNAs in the absence of
BMP2. Transfection of $\mathrm{C} 2 \mathrm{C} 12$ and $\mathrm{C} 3 \mathrm{H} / 10 \mathrm{~T} 1 / 2$ cells with pH_MetLuc hybrid plasmids was surprisingly not sufficient to induce osteogenic differentiation (quantified by ALP activity), independent of the used shRNA, while the hybrid vectors did (Fig. 2). rhBMP2 protein treatment $(150 \mathrm{ng} / \mu \mathrm{L})$ resulted in an increase in ALP enzyme. In C2C12, this positive control exceeded the osteogenic effect of hybrid plasmid transfection.

Hybrid vectors increased BMP2 protein levels in C2C12 and $\mathrm{C} 3 \mathrm{H} / \mathbf{1 0 T} 1 / 2$ cells after transfection

To evaluate the influence of the miRNA expression cassette on the expression level of the adjacent BMP2 cassette, $\mathrm{C} 2 \mathrm{C} 12$ and $\mathrm{C} 3 \mathrm{H} / 10 \mathrm{~T} 1 / 2$ cells were transfected with hybrid vectors (Fig. 3) for subsequent quantification of secreted BMP2. To track timedependent expression changes, supernatants of transfected cells were collected at day 3 and 6 . In both studied cell types, the highest BMP2 protein levels were reached when cells were transfected with either $\mathrm{pH} \_\mathrm{BMP} 2_{\mathrm{ADV}} 148 \mathrm{~b}, \mathrm{pH}$ _BMP2 $2_{\mathrm{ADV}} 590$ or $\mathrm{pH} \_\mathrm{BMP} 2{ }_{\mathrm{ADV}} 20 \mathrm{a}$. The lowest concentration of BMP2

\section{$\mathrm{C} 2 \mathrm{C} 12$}

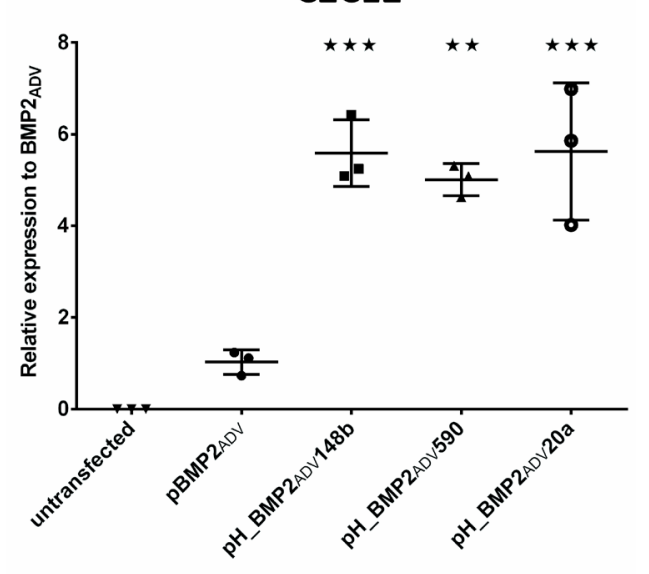

\section{$\mathrm{C} 3 \mathrm{H} / 10 \mathrm{~T} 1 / 2$}

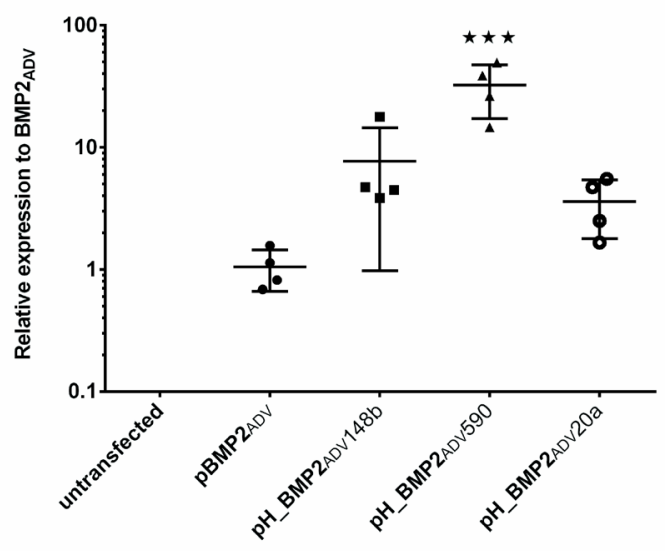

\section{CHO-K1}

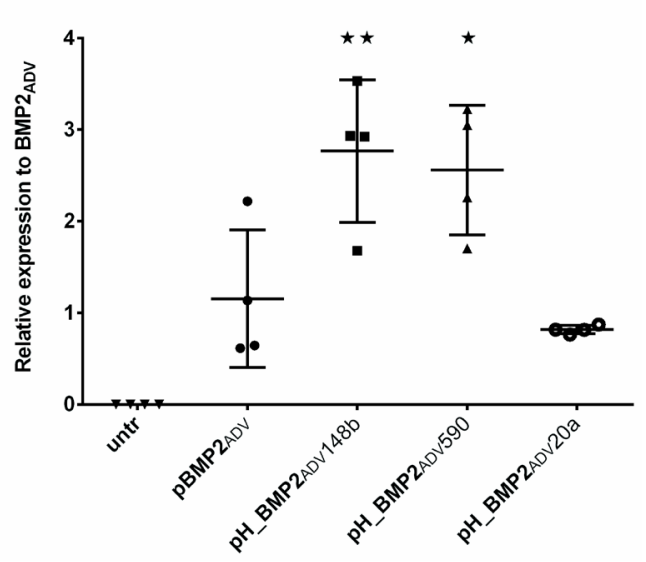

Fig. 5. RT-qPCR gene expression analysis. C2C12, C3H/10T1/2 and CHO-K1 cellular mRNA after transfection with $\mathrm{pH} \_\mathrm{BMP} 2{ }_{\mathrm{ADV}} 148 \mathrm{~b}, \mathrm{pH} \_\mathrm{BMP} 2{ }_{\mathrm{ADV}} 590, \mathrm{pH} \_\mathrm{BMP} 2_{\mathrm{ADV}} 20$ a or pBMP2 ${ }_{\mathrm{ADV}}$ plasmid. Quantification of $\mathrm{BMP} 2_{\mathrm{ADV}}$ transcript levels was performed $3 \mathrm{~d}$ after transfection. Expression data represented as $\Delta \Delta \mathrm{Ct}$ values relative to $\mathrm{pBMP} 2_{\mathrm{ADV}}$. Reference genes Hprt $(\mathrm{C} 2 \mathrm{C} 12$ and $\mathrm{C} 3 \mathrm{H} / 10 \mathrm{~T} 1 / 2)$ and Actr5 (CHO-K1) were used for normalisation. C3H/10T1/2 data are depicted logarithmically. Averaged data are presented as means $\pm \mathrm{SD}, n \geq 3$. 
protein was detected in supernatants when cells were transfected with $\mathrm{pBMP} 2_{\mathrm{ADV}}$. Only in $\mathrm{C} 2 \mathrm{C} 12$ at day 3, $\mathrm{pH}$ _BMP2 ${ }_{\mathrm{ADV}} \mathrm{scr}$ showed significantly higher therapeutic protein levels when compared to $\mathrm{pBMP} 2_{\mathrm{ADV}}$, which was followed by a strong decrease over the investigated time course.

\section{Homogeneous expression of BMP2 in CHO-K1 cells upon hybrid vector transfection}

To exclude one possible cause for BMP2 variation - BMP2 consumption due to cellular uptake during cell differentiation (Garzon-Alvarado et al., 2014) - osteogenic-differentiation-incompetent CHO-K1 cells were transfected with selected hybrid plasmids. Interestingly, they showed comparable BMP2 expression levels over a $4 \mathrm{~d}$ time course (Fig. 4). At day 2 and 4 after transfection, no significant difference between construct groups was detectable.

Quantification of $B M P 2_{A D V}$ and miRNA transcription levels and subsequent localisation of miRNAs

To evaluate consistency of gene transcription (mRNA levels) and BMP2 protein production, amounts of $B M P 2_{A D V}$ mRNA produced by different hybrid vector constructs (harbouring different miRNAs) were quantified using RT-qPCR (Fig. 5) for subsequent comparison with BMP2 protein levels. Hybrid-vectorgenerated mRNA levels of $B M P 2_{A D V}$ significantly exceeded those of $\mathrm{pBMP} 2_{\mathrm{ADV}}$ control (conventional plasmid lacking miRNA expression cassette). In CHO-K1 cells, $\mathrm{pH} \_\mathrm{BMP} 2_{\mathrm{ADV}} 148 \mathrm{~b}$ and $\mathrm{pH}$ $\mathrm{BMP} 2_{\mathrm{ADV}} 590$ induced the largest amounts of $B M P 2_{A D V}$ mRNA, whereas $\mathrm{pH} \_\mathrm{BMP} 2_{\mathrm{ADV}} 20 \mathrm{a}$ and $\mathrm{pBMP} 2_{\mathrm{ADV}}$ reached similar relative expression levels. In C2C12 cells, all hybrid constructs displayed significantly larger amounts of $B M P 2_{A D V}$ mRNA than $\mathrm{pBMP} 2_{\mathrm{ADV}}$ control. Interestingly, $\mathrm{C} 3 \mathrm{H} / 10 \mathrm{~T} 1 / 2$ cells transfected with $\mathrm{pH}$ _BMP2 2590 resulted in significantly higher transgene mRNA expression when compared with other hybrid plasmid constructs harbouring other miRNA sequences. Untransfected cells served as a negative control, lacking a primer-specific transcript.

To verify miRNAs' overexpression, determine their intracellular versus secreted levels and understand their potential paracrine effects, $\mathrm{C} 3 \mathrm{H} / 10 \mathrm{~T} 1 / 2$ cells were transfected with the chosen hybrid vector constructs. $\mathrm{pBMP} 2_{\mathrm{ADV}}$ plasmid transfection served as normalisation sample for osteogenic expression of miRNAs 20a-5p, 148b-3p and 590-5p. Intracellular and extracellular miRNA levels were analysed (Fig. 6), always comparing miRNA transcript levels after transfection with the plasmid expressing the same miRNA. Baseline miRNA levels were similar intracellularly and extracellularly (data not shown). In comparison to cells transfected with $\mathrm{pBMP} 2_{\mathrm{ADV}}$, a $57.0 \pm 5.3$-fold increase of miR-148b$3 p$ expression levels was detected intracellularly, while an $80.2 \pm 30.1$-fold increase was observed in extracellular supernatants. Elevated expression levels were also observed for miRNAs 20a-5p and 590-5p after corresponding hybrid plasmid transfection. Abundance of miR-20a-5p increased intracellularly by $1.9 \pm 0.1$ and extracellularly by $1.9 \pm 0.7$-fold. Expression level of miR-590-5p changed $18.0 \pm 9.6-$ fold upon transfection intracellularly and $5.3 \pm 2.1-$ fold in extracellular supernatant samples. Secretion of these miRNAs into body fluids has indeed been observed in the context of bone metabolism and dysfunctions (et al., 2013; Zhang et al., 2020).

miRNA590 exhibited the highest potential for osteoinduction in $\mathrm{C} 2 \mathrm{C} 12$ and $\mathrm{C} 3 \mathrm{H} / 10 \mathrm{~T} 1 / 2$ cells

Biomarkers for osteoinduction, Alpl, Col1a1, Runx2 and $O C N$, were found to be differentially up-regulated in $\mathrm{C} 2 \mathrm{C} 12$ and $\mathrm{C} 3 \mathrm{H} / 10 \mathrm{~T} 1 / 2$ cells after transfection with hybrid constructs (Fig. 7). In C3H/10T1/2 cells, pH $\mathrm{BMP} 2_{\mathrm{ADV}} 148 \mathrm{~b}, \mathrm{pH} \_\mathrm{BMP} 2_{\mathrm{ADV}} 590$ and pH_BMP2 ${ }_{\mathrm{ADV}} 20 \mathrm{a}$ reached significantly higher levels of OCN mRNA
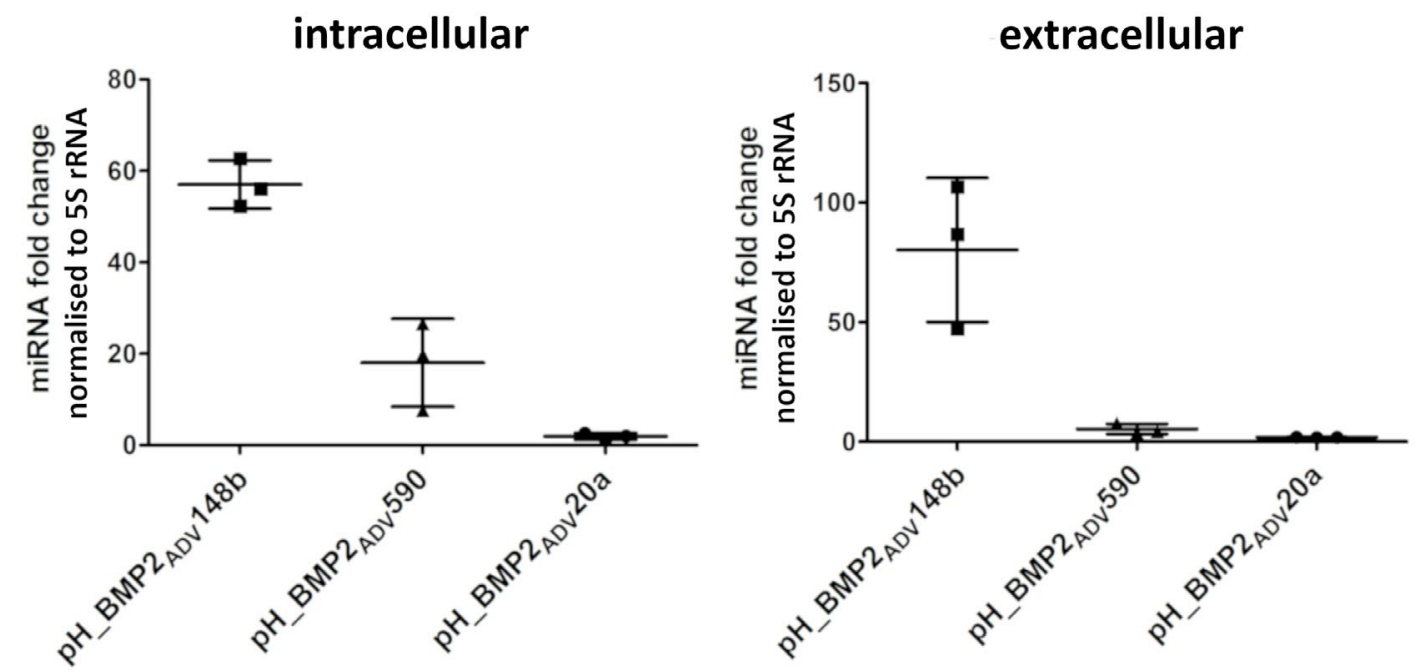

Fig. 6. Intracellular and extracellular miRNA localisation profiles $2 \mathrm{~d}$ after transfection of C3H/10T1/2 cells. Data were normalised to reference genes U6 snRNA, 5S rRNA (intracellular) and RNA Spike-In (extracellular) and are presented relative to $\mathrm{pBMP}_{\mathrm{ADV}}$ transfection (vector lacking miRNA expression cassette) as means $\pm \mathrm{SD}, n=3$. 
$\mathrm{C} 2 \mathrm{C} 12$

$\mathrm{C} 3 \mathrm{H} / 10 \mathrm{~T} 1 / 2$

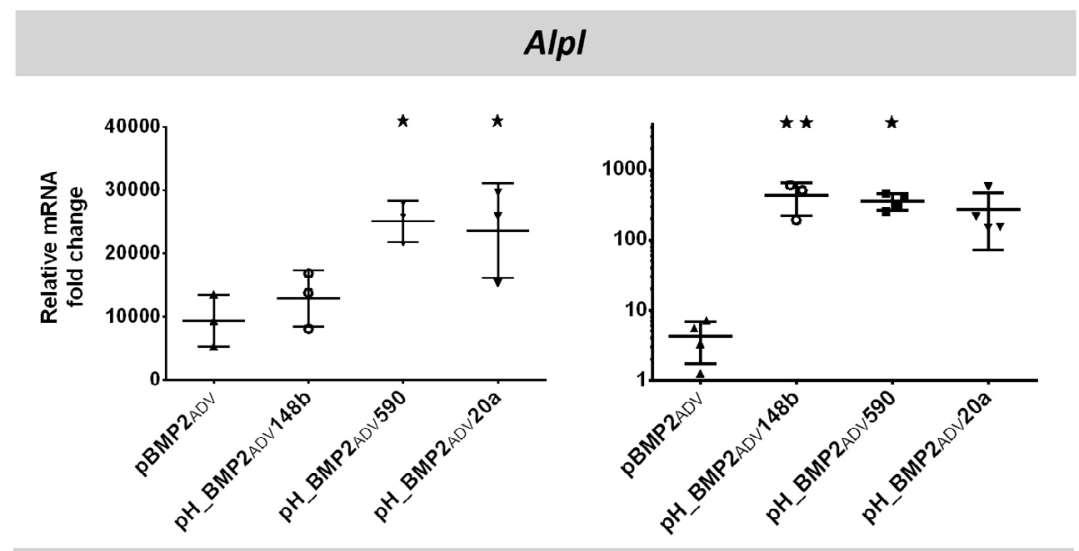

Col1a1
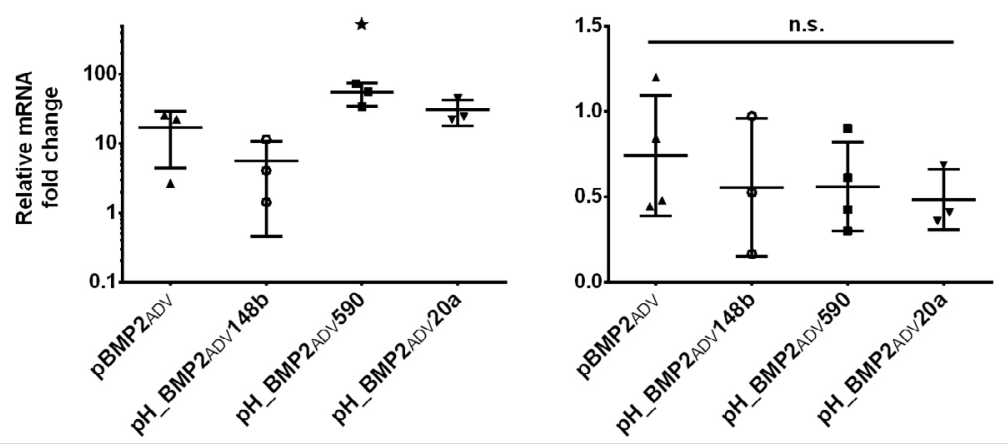

Runx2
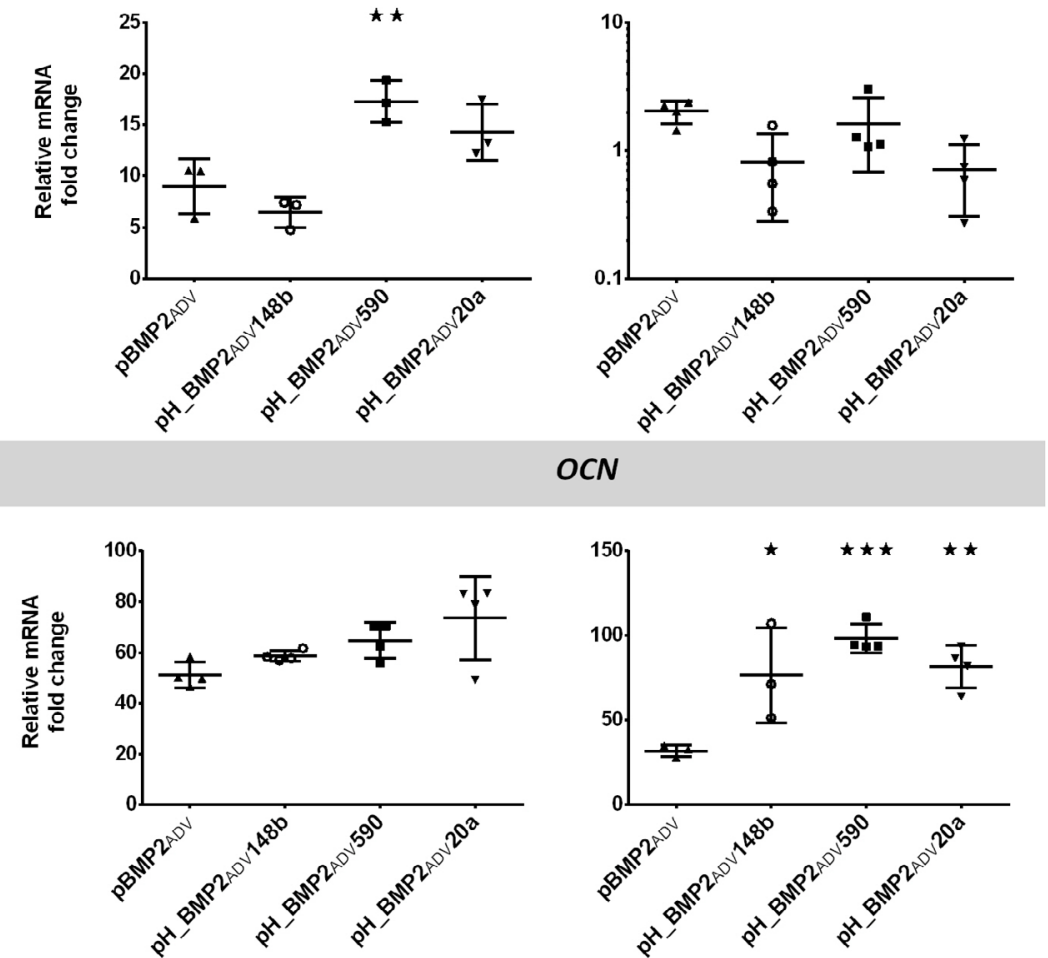

Fig. 7. RT-qPCR analysis of C2C12 and C3H/10T1/2 cell lines. Cells were transfected with pH_BMP2 ${ }_{\mathrm{ADV}} 148 \mathrm{~b}$, pH_BMP2 2590 , pH_BMP2 ${ }_{\mathrm{ADV}} 20 \mathrm{a}$ or $\mathrm{pBMP} 2_{\mathrm{ADV}}$ plasmid. Total RNA was collected 3 (C2C12) and $6 \mathrm{~d}$ $(\mathrm{C} 3 \mathrm{H} / 10 \mathrm{~T} 1 / 2)$ after transfection. Threshold cycles $(\mathrm{Ct})$ of each reaction, relative to untransfected control group, were normalised to those obtained for reference mRNA using $2^{-\Delta \Delta C t}$ method. Individual data sets are depicted in a logarithmic scale. Statistical differences were determined by one-way ANOVA followed by Tukey post-hoc test analysis, comparing all groups with $\mathrm{pBMP} 2_{\mathrm{ADV}}$. Averaged data are presented as means $\pm \mathrm{SD}, n \geq 3$. 
when compared with conventional $\mathrm{pBMP} 2_{\mathrm{ADV}}$ plasmid. All 3 hybrid vectors led to significantly increased OCN mRNA counts. No difference in Col1a1 mRNA expression was detected between transfected groups and untransfected control. In C2C12, Alpl mRNA was up-regulated in all transfected cells, especially $\mathrm{pH}$ _BMP2 2 ADv 590 and pH_BMP2 2 ADv $20 \mathrm{a}$ led to a significantly larger mRNA increase. In addition, Runx2 mRNA levels were up-regulated the most in C2C12 cells transfected with $\mathrm{pH} \mathrm{BMP}_{\mathrm{ADV}} 590$ and pH_BMP2 20 aDv. Colla1 expression significantly increased upon transfection with $\mathrm{pH} \_\mathrm{BMP} 2_{\mathrm{ADV}} 590$. mRNA levels were quantified 3 (C2C12) and $6 \mathrm{~d}$ $(\mathrm{C} 3 \mathrm{H} / 10 \mathrm{~T} 1 / 2)$ after transfection.

\section{Regulation of mRNAs after hybrid vector transfection suggested miRNA-specific mRNA targets}

To confirm that the 3 miRNAs showed specific patterns of mRNA regulation, NGS of mRNAs was performed $3 \mathrm{~d}$ after transfecting $\mathrm{C} 3 \mathrm{H} / 10 \mathrm{~T} / 1$ cells with $\mathrm{pH}$ _BMP2 $2_{\mathrm{ADV}} 20 \mathrm{a}, \mathrm{pH}$ _BMP2 ${ }_{\mathrm{ADV}} 148 \mathrm{~b}$, $\mathrm{pH} \_\mathrm{BMP} 2$ ADV 590 and $\mathrm{pBMP} 2_{\mathrm{ADV}}$ plasmid. All hybrid RNA profile data were analysed relative to $\mathrm{PBMP} 2{ }_{\mathrm{ADV}}$ serving as control. To exclude effects of $B M P 2$ alone, the mRNA transcription profiles were compared to $\mathrm{pBMP} 2_{\mathrm{ADV}}$. NGS data were controlled for total and mapped reads. Raw data were submitted to GEO (Web ref. 2) (accession number GSE166110). Principal component analysis showed clustering of the 3 independent transfections, whereby $\mathrm{pBMP} 2_{\mathrm{ADV}} 590$ hybrid was more distinct than the others (Fig. 8a). Transfection of cells with $\mathrm{pH}$ _BMP2 2 ADv 590 resulted in identification of 532 significantly up-regulated and 463 significantly down-regulated genes. While $\mathrm{pH} \_\mathrm{BMP} 2{ }_{\mathrm{ADV}} 20 \mathrm{a}$ resulted in an up-regulation of 78 and a down-regulation of 100 genes, transfection with $\mathrm{pH}$ _BMP2 ${ }_{\mathrm{ADV}} 148 \mathrm{~b}$ showed 68 genes to be upregulated significantly and 32 genes to be down- regulated significantly. Fig. $8 \mathbf{b}$ shows the number of significantly up-regulated and Fig. 8c downregulated genes after hybrid vector versus $B M P 2_{A D V^{-}}$ only transfection. Overlapping areas represent significantly affected genes common to all 3 hybrid vectors (Table 3,4). Since all 3 hybrid constructs resulted in increased osteogenic differentiation in vitro, this could be reflected in the small number of jointly regulated mRNAs, which might be indispensable for boosting osteogenesis and on which the very specific and different regulatory activity of the 3 different miRNAs converge. Such a specific activity of the single miRNAs is supported by the fact that the differentially expressed mRNAs after miR-590, 20a and $148 \mathrm{~b}$ are prevailing.

To corroborate specific effects of the 3 single miRNAs, the study hypothesis was that confirmed target mRNAs would be down-regulated after transfection. Therefore, the significantly downregulated mRNAs were compared to the complete list of validated specific miRNA targets derived from TarBase (Karagkouni et al., 2018) (Fig. 9). Indeed, of all significantly down-regulated genes after transfection with $\mathrm{pH}$ _BMP2 2 5Dv $590,134(28.57 \%)$ were validated targets (Fig. 9a). For pH_BMP2 ${ }_{\mathrm{ADV}} 20 \mathrm{a}$, a lower fraction of 23 mRNAs (23.00\%) of total significantly down-regulated genes was matched with validated targets (Fig. 9b). pH_BMP2 $2_{\mathrm{ADV}} 148 \mathrm{~b}$ led to the downregulation of 2 validated targets, which was $6.25 \%$ of all significantly down-regulated genes affected by this plasmid (Fig. 9c). Summarised, these data prompted the selection of the BMP2/miR-590-5p hybrid vector for an in vivo proof-of-principle study.

\section{In vivo transfection of $\mathrm{pH} \_\mathrm{BMP} 2_{\mathrm{ADv}} 590$ indicated} osteogenic potential of hybrid plasmid pH_BMP2 25 SDO , as one of the most promising plasmids regarding osteoinductive potential in vitro, was directly compared to the original $\mathrm{pBMP} 2_{\mathrm{ADV}}$
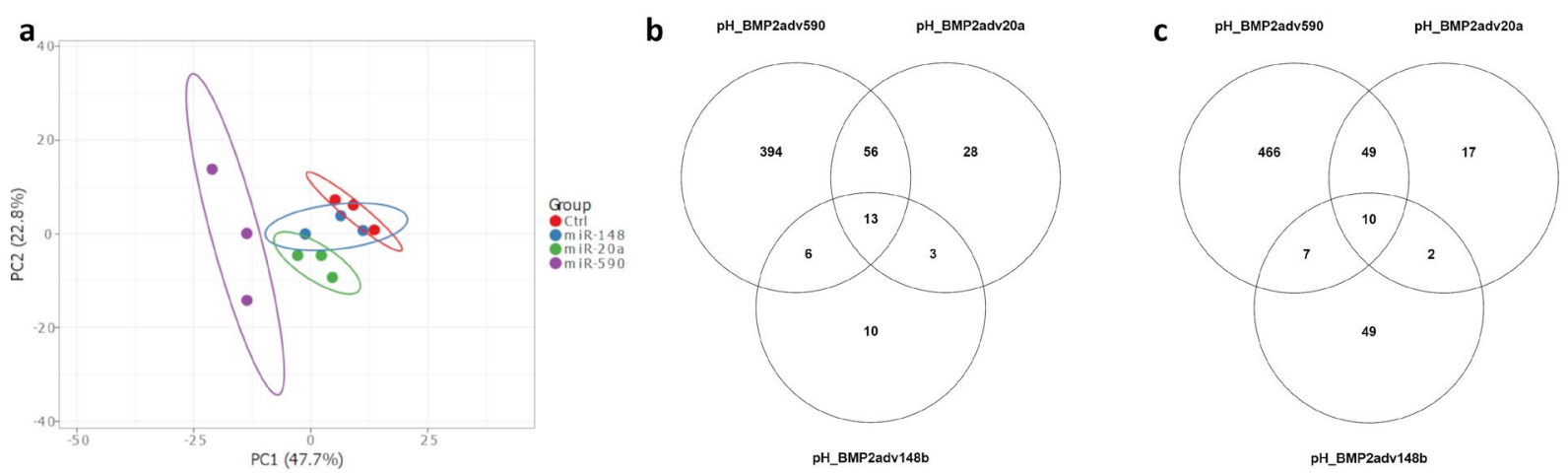

Fig. 8. NGS principle components analysis and commonly regulated genes. (a) Principal component analysis of NGS data showed clustering of the 3 independent transfections of $\mathrm{C} 3 \mathrm{H} / 10 \mathrm{~T} / 1$ cells with either $\mathrm{pH} \_\mathrm{BMP} 2_{\mathrm{ADV}} 148 \mathrm{~b}, \mathrm{pH} \_\mathrm{BMP} 2_{\mathrm{ADV}} 20 \mathrm{a}$ or $\mathrm{pH} \_\mathrm{BMP} 2_{\mathrm{ADV}} 590$, whereby $\mathrm{pBMP} 2_{\mathrm{ADV}} 590$ hybrid was more distinct than the others. NGS was used to identify significantly (b) down- and (c) up-regulated genes $3 \mathrm{~d}$ after transfection of $\mathrm{C} 3 \mathrm{H} / 10 \mathrm{~T} / 1$ cells with either $\mathrm{pH} \_\mathrm{BMP} 2_{\mathrm{ADV}} 148 \mathrm{~b}, \mathrm{pH} \_\mathrm{BMP} 2$ aDv $20 \mathrm{a}$ or pH_BMP2 250 . Generated data were calculated relative to transfection of $\mathrm{C} 3 \mathrm{H} / 10 \mathrm{~T} / 1$ cells with $\mathrm{pBMP}{ }_{\mathrm{ADV}}$. Overlapping areas indicate the number of commonly regulated genes, with 13 targets significantly down- and 10 targets significantly up-regulated in all three transfection settings. 
Table 3. List of 13 common significantly down-regulated genes.

\begin{tabular}{|c|c|c|}
\hline Abbreviated gene name & $\begin{array}{l}\text { Full gene name } \\
\end{array}$ & Ensemble code \\
\hline Gadd $45 b$ & Growth arrest and DNA-damage-inducible 45 beta & ENSMUSG00000015312 \\
\hline Resf1 & Retroelement silencing factor 1 & ENSMUSG00000032712 \\
\hline Klf6 & Kruppel-like factor 6 & ENSMUSG00000000078 \\
\hline Rnd1 & Rho family GTPase 1 & ENSMUSG00000054855 \\
\hline Csf1 & Colony stimulating factor 1 & ENSMUSG00000014599 \\
\hline$M+2$ & Metallothionein 2 & ENSMUSG00000031762 \\
\hline Adamts5 & $\begin{array}{l}\text { A disintegrin-like and metallopeptidase (reprolysin } \\
\text { type) with thrombospondin type } 1 \text { motif, } 5\end{array}$ & ENSMUSG00000022894 \\
\hline 2610008E11Rik & RIKEN cDNA 2610008E11 gene & ENSMUSG00000060301 \\
\hline Gadd $45 g$ & $\begin{array}{c}\text { Growth arrest and DNA-damage-inducible } 45 \\
\text { gamma }\end{array}$ & ENSMUSG00000021453 \\
\hline Ajuba & Ajuba LIM protein & ENSMUSG00000022178 \\
\hline SnhG15 & Small nucleolar RNA host gene 15 & ENSMUSG00000085156 \\
\hline $\mathrm{Ccl} 2$ & Chemokine (C-C motif) ligand 2 & ENSMUSG00000035385 \\
\hline 2410006H16Rik & RIKEN cDNA 2410006H16 gene & ENSMUSG00000086841 \\
\hline
\end{tabular}

Table 4. List of 10 common significantly up-regulated genes.

\begin{tabular}{|c|c|c|}
\hline Abbreviated gene name & Full gene name & Ensemble \\
\hline Rpl41 & Ribosomal protein L41 & ENSMUSG00000093674 \\
\hline Myl6 & $\begin{array}{c}\text { Myosin, light polypeptide 6, alkali, smooth muscle } \\
\text { and non-muscle }\end{array}$ & ENSMUSG00000090841 \\
\hline Adgrg2 & Adhesion G protein-coupled receptor G2 & ENSMUSG00000031298 \\
\hline Rgs2 & Regulator of G-protein signaling 2 & ENSMUSG00000026360 \\
\hline$M m p 2$ & Matrix metallopeptidase 2 & ENSMUSG00000031740 \\
\hline Hey1 & Hairy/enhancer-of-split related with YRPW motif 1 & ENSMUSG00000040289 \\
\hline Pass & Prosaposin/Spingolipid activator protein & ENSMUSG00000004207 \\
\hline Krt13 & Kreatin 13 & ENSMUSG00000044041 \\
\hline Cdsn & Corneodesmosin & ENSMUSG00000039518 \\
\hline$M m p 11$ & Matrix metallopeptidase 11 & ENSMUSG00000000901 \\
\hline
\end{tabular}

plasmid in an in vivo ectopic-bone mouse model. To allow for optimal intra-animal comparison, each hind limb was transfected with one of the plasmids. 8 weeks after transfection, hind limbs were scanned ex vivo for ectopic mineralisation by high-resolution computed tomography (Fig. 10). None of the 4 transfections with the negative control luciferase plasmid showed relevant mineralisation (Fig. 10c). In all animals but one, mineralised volumes were larger when transfected with the hybrid plasmid instead of the original $\mathrm{pBMP} 2_{\mathrm{ADV}}$. Four out of 6 in vivo muscle transfections with $\mathrm{pH} \_\mathrm{BMP} 2_{\mathrm{ADV}} 590$, but only 1 out of 6 pBMP2 $2_{\mathrm{ADV}}$ transfections, showed significant mineralisation (Fig. 11). Ectopic-bone volume varied strongly and showed substantial differences in shape.

\section{Histological analysis confirmed ectopic mineralisation}

Histological evaluation of transfected muscle tissue sites, 8 weeks after plasmid injection, confirmed formation of mineralisation in accordance with $\mu \mathrm{CT}$ images. Upon standard HE and von Kossa treatment, muscle tissue transfected with $\mathrm{pBMP}_{\mathrm{ADV}}$ and $\mathrm{pH}$ $\mathrm{BMP} 2_{\mathrm{ADV}} 590$ hybrid plasmid revealed mineralised areas (Fig. 12,13). Collagen type 2-enriched matrix was shown by positive immunostaining within the area of interest (brown). In contrast, transfection with luciferase control plasmid did not induce intramuscular mineralisation. Response differences to transfection with the same plasmid were visible in histology. While $\mathrm{pBMP} 2_{\mathrm{ADV}}$ \#1 showed extensive mineralisation within the muscle tissue, the other hind limb transfected with $\mathrm{pBMP} 2_{\mathrm{ADV}} \# 2$ showed distinctly less mineralisation. Similarly, the variability in osteoinduction of the same plasmids became apparent in histological images of $\mathrm{pH} \_\mathrm{BMP} 2$ ADV $590 \# 1$, $\# 2$ and \#3, where \#3 revealed the smallest area of mineralisation.

\section{Discussion}

Recent developments in terms of miRNA expression profiles and subsequent target silencing within the setting of tissue regeneration offer an additional approach to enhance the biological impact of non-viral gene therapy. The main objective of the present study was to utilise miRNA gene-regulation 
to further increase the efficacy of the previously published osteogenic vector system (Hacobian et al., 2016). This was accomplished by combining an optimised $B M P 2\left(B M P 2_{A D V}\right)$ under the control of an EF1 $\alpha$ minimal promoter with different shRNA sequences regulated by a human RNA polymerase III U6 promoter. In a previous study, Hacobian et al. (2016) showed that the EF1 $\alpha$ promoter regulation is superior to the CMV promoter in terms of expression level and duration. The U6 promoter was chosen due to its well-studied, competent and constitutive smallRNA-transcription properties (Duvoisin et al., 2012).

\section{a}

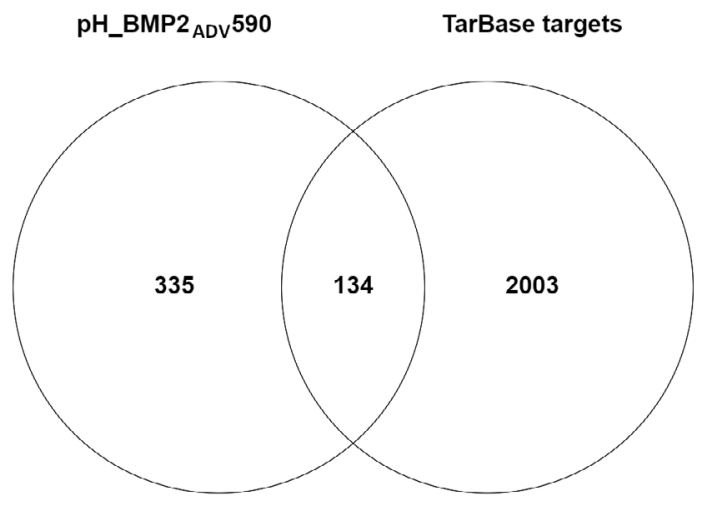

b

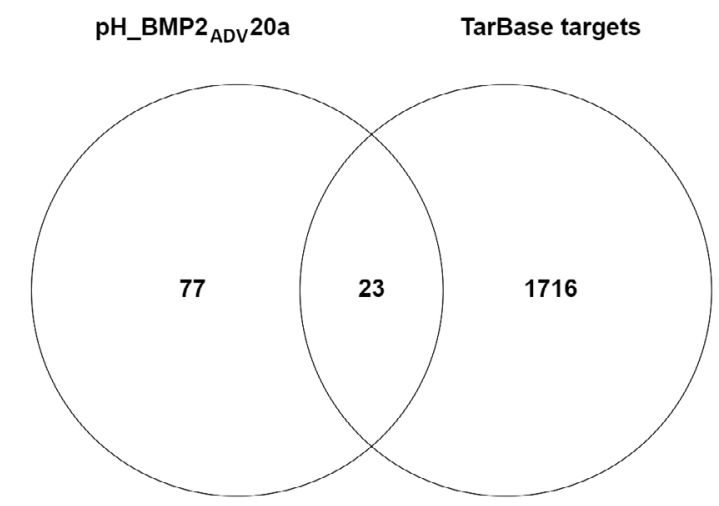

C

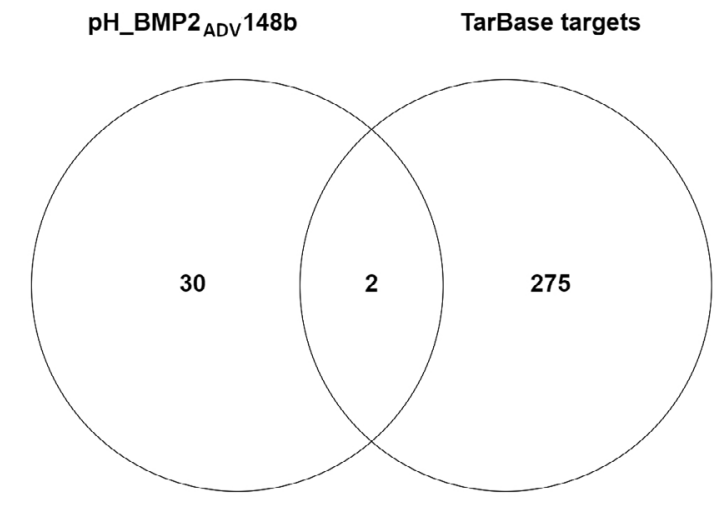

Fig. 9. Identified miRNA-targets versus validated targets. The diagram depicts the significantly downregulated genes $3 \mathrm{~d}$ after transfection of $\mathrm{C} 3 \mathrm{H} / 10 \mathrm{~T} / 1$ cells with (a) $\mathrm{pH}$ _BMP2 ${ }_{\mathrm{ADV}} 590$, (b) $\mathrm{pH} \_\mathrm{BMP} 2_{\mathrm{ADV}} 20 \mathrm{a}$, or (c) $\mathrm{pH}$ _BMP2 ${ }_{\mathrm{ADV}} 148 \mathrm{~b}$, identified by NGS and mapped against all miRNA-specific validated targets derived from TarBase (Karagkouni et al., 2018).
To validate the miRNA expression system, luciferase-reporter gene activity was down-regulated via expression of a specific anti-Luc shRNA from a co-transfected plasmid. When comparing forward and reverse orientation (with regard to the coexpressed luciferase transgene) of the U6 promoter anti-Luc hairpin expression cassette, significantly more reduction in luciferase protein expression was facilitated by the forward expression direction (Fig. 1b). The existence of the promoter interference phenomena has been described before (Shearwin et al., 2005), such as for a constitutive CMV-promoter co-expression system (Feichtinger et al., 2014a). There, transgene co-expression from the same plasmid lead to lower protein levels when compared to the expression from two distinct plasmids, indicating a negative cross talk between the RNA polymerase II promoters. On the other hand, the present study indicated a positive influence of synchronic polymerase II and III promoter activity. Therefore, the synchronous rather than the asynchronous or bidirectional arrangement of expression units was adopted for the osteogenic hybrid plasmids.

To test the hybrid system in an osteogenic set-up, 3 candidate miRNAs (hsa-miR-148b-3p, hsa-miR-590$5 p$, hsa-miR-20a-5p) and a control scrambled anti-Luc miRNA were selected for further experiments and incorporated into the hybrid vector system (Fig. 1). To evaluate the isolated osteogenic potential of each miRNA, hybrid plasmids were tested against control plasmids pH_MetLuc, which expressed Metridia longa luciferase instead of $B M P 2_{A D V}$. Keeping the expression occurrence of reporter gene and shRNA constant, whilst excluding influence of the growth factor was not sufficient to increase ALP enzyme activity in $\mathrm{C} 2 \mathrm{C} 12$ and $\mathrm{C} 3 \mathrm{H} / 10 \mathrm{~T} 1 / 2$ cell lines at the selected time points (Fig. 2). The murine myoblast cell line $\mathrm{C} 2 \mathrm{C} 12$ was chosen as an in vitro osteogenic transdifferentiation model, due to its rapid cellular response following BMP2 treatment and the functional resemblance to the in vivo experimental setup, where mouse muscle tissue was transfected. To test the plasmids in a non-osteogenic multipotent cell line, C3H/10T1/2 cells were also used for in vitro transfection experiments. Albeit miR-148b-3p alone can result in differentiation of hASCs into an osteogenic lineage (Qureshi et al., 2013), it was not possible to confirm this effect at selected time points in the experiments using $\mathrm{C} 2 \mathrm{C} 12$ and $\mathrm{C} 3 \mathrm{H} / 10 \mathrm{~T} 1 / 2$ cell lines. A possible explanation may be a prolonged processing time and a lower overall concentration of active miR-148b-3p, when introduced via transient gene expression as compared to transfection with particle-conjugated pre-processed single stranded miR-148b-3p (Qureshi et al., 2013). The early ALP assay sampling time point ( $3 \mathrm{~d}$ ) for C2C12 was based on the observation of myogenic changes in morphology, which are thought to be irreversible, as early as $4 \mathrm{~d}$ after transfection (data not shown), if no BMP2 transgene was co-introduced. At the designated time points, $\mathrm{C} 2 \mathrm{C} 12$ as well as C3H/10T1/2 


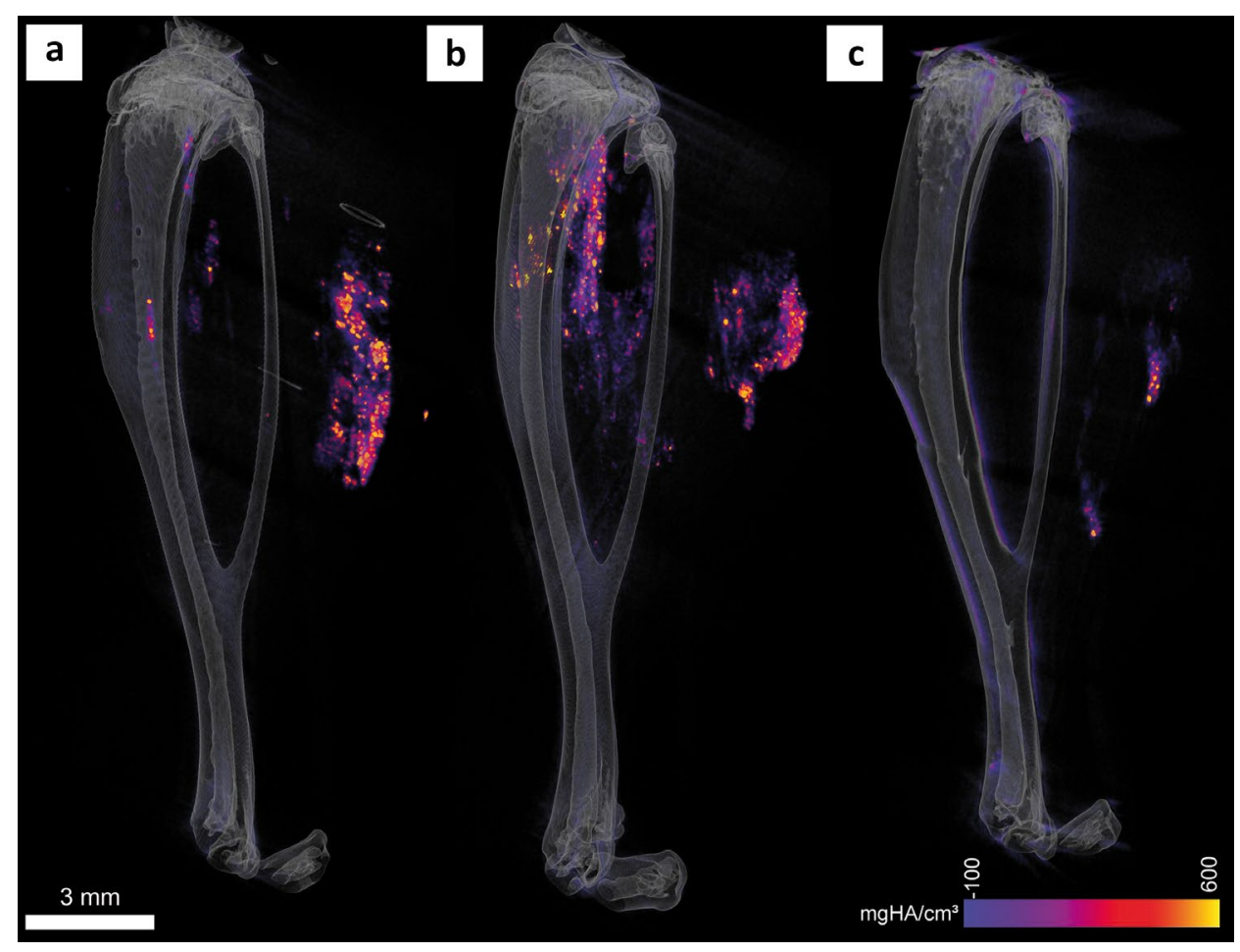

Fig. 10. Representative $\mu \mathrm{CT}$-images of mouse hind limbs 8 weeks after transfection. Coloured areas indicate mineralisation. Changes of shading, from violet to yellow, increase with density. Bones (tibia and fibula) are visualised in grey. (a) $\mathrm{pBMP}_{\mathrm{ADV}}$; (b) $\mathrm{pH}_{-} \mathrm{BMP2}{ }_{\mathrm{ADV}} 590$; (c) luciferase control plasmid.

\section{Comparison per animal}

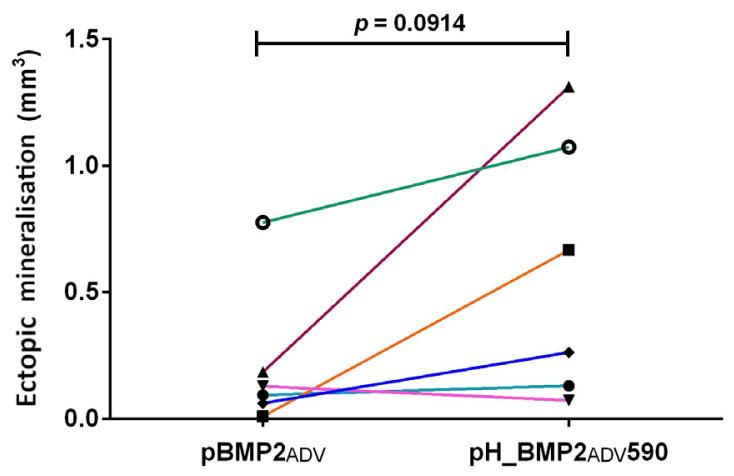

Fig. 11. Intra-animal comparison of ectopic mineralised volumes. Each line represents a single animal and each dot the limb harbouring the tested plasmid.

cells (6 d time point) showed strong induction of ALP enzyme activity when treated with rhBMP2 protein $(150 \mathrm{ng} / \mathrm{mL})$. Although $\mathrm{pBMP}_{\mathrm{ADV}}$ induced an increase in ALP activity, compared to the $\mathrm{pH}_{-}$ MetLuc group, this difference was not statistically significant. $\mathrm{C} 3 \mathrm{H} / 10 \mathrm{~T} 1 / 2$ showed a delayed induction of differentiation as compared to $\mathrm{C} 2 \mathrm{C} 12$. Therefore, a later sampling time point for ALP assay was chosen.

Interestingly, ELISA showed that BMP2 protein amounts produced by cells transfected with different hybrid vectors differed significantly between studied cell types (C2C12 and C3H/10T1/2) (Fig. 3). The detected protein was a combination of endogenous and transgenic Bmp2, as these are not distinguishable by their amino-acid sequence. The obtained results may be affected by enhanced endogenous protein production by simultaneously introduced miRNA (positive feedback loop of Bmp2 production). One of hsa-miR-148b-3p's targets predicted by the miRTargetLink free online software tool (Hamberg et al., 2016) was Rock1, which when inhibited has been shown to increase transcription factor Runx2 nuclear translocation as well as differentiation and mineralisation of rat calvarial osteoblasts (Prowse et al., 2013), demonstrating the pro-osteogenic properties of miR-148b-3p. miR-148b-3p affects osteogenic differentiation of hMSCs in a positive manner, as verified by increased ALP enzyme activity (Schoolmeesters et al., 2009). Furthermore, in hASCs, baculovirus-mediated expression of the same miRNA improves osteogenesis in vitro and implantation of hASCs co-expressing BMP2/miR-148b-3p accelerates as well as ameliorates bone healing and remodelling in a critical-size calvarial defect model (Liao et al., 2014). Target prediction of hsa-miR-20a-5p revealed incongruent results. On one hand, Bmpr 2 and Tgfbr2, both important for BMP2-mediated cellular signalling, were supposedly down-regulated. Therefore, reduced osteogenic differentiation would be expected. On the other hand, the same non-coding RNA knocks-down BMP2 antagonists Crim1, BAMBI as well as PPARG (Wilkinson et al., 2003; Umulis et al., 2009; Zhang et al., 2011). Measurement of knockdown efficacy of these targets might give more insight into the hsa-miR-20a-5p mode of action. In the case of hsa-miR-590-5p, strong evidence exists for the targets TGFBR2 (Ekhteraei-Tousi et al., 2015) and Smad (Vishal et al., 2017), a corepressor of Runx2. Reduced repression of the transcription factor RUNX2 enables elevated BMP2-induced osteogenic gene expression. The complementary seed sequence hsa-miR-590-3p induces osteogenic differentiation in MSCs. The underlying mechanism includes knockdown of 


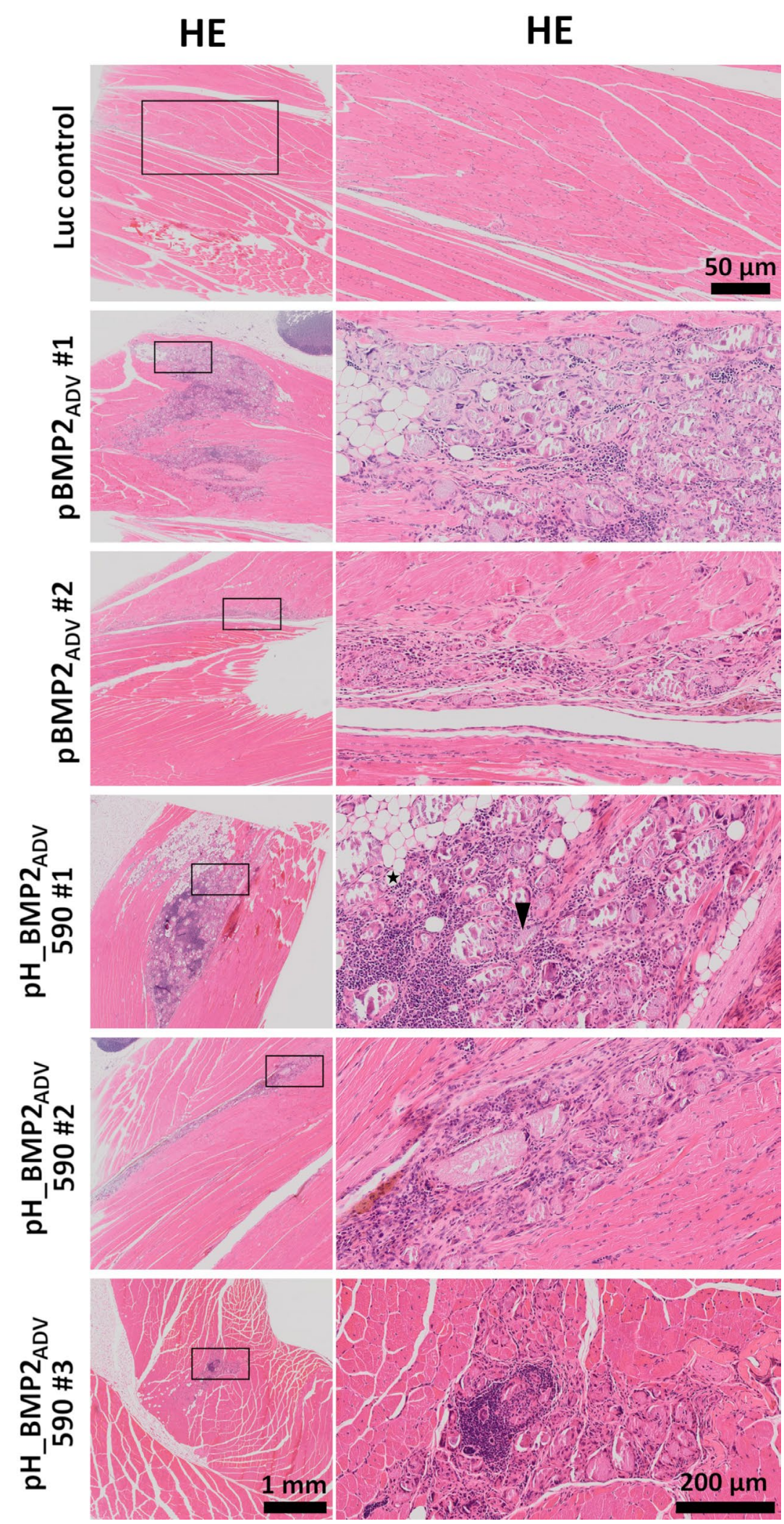

Fig. 12. Histology of intramuscular mineralisation 8 weeks after plasmid transfection. Higher magnification in the right column of the area of interest is indicated by a black rectangle in the left column. HE staining of muscle tissue transfected with luciferase control, pBMP2 ${ }_{\mathrm{ADV}}$ or pH_BMP2 ${ }_{\mathrm{ADV}} 590$. Mineralised ectopic tissue (arrowhead) is indicated by violet, brittle areas embedded within the muscle tissue in the HE staining, blood vessels (not shown) and fatty tissue (star) are also present within the transformed tissue. To underline variability of induced mineralisation, samples representing high and low response to transfection were included, labelled with \#1 (high response) and \#2 (low response) for the pBMP2 plasmid. Histological samples $\mathrm{pH} \_\mathrm{BMP} 2_{\mathrm{ADV}} 590 \# 1$ and $\mathrm{pH} \_\mathrm{BMP} 2_{\mathrm{ADV}} 590 \# 2$ showed high response, while \#3 represented a low response sample upon transfection. Scale bars at the bottom of images account for all images of column except if indicated differently. 


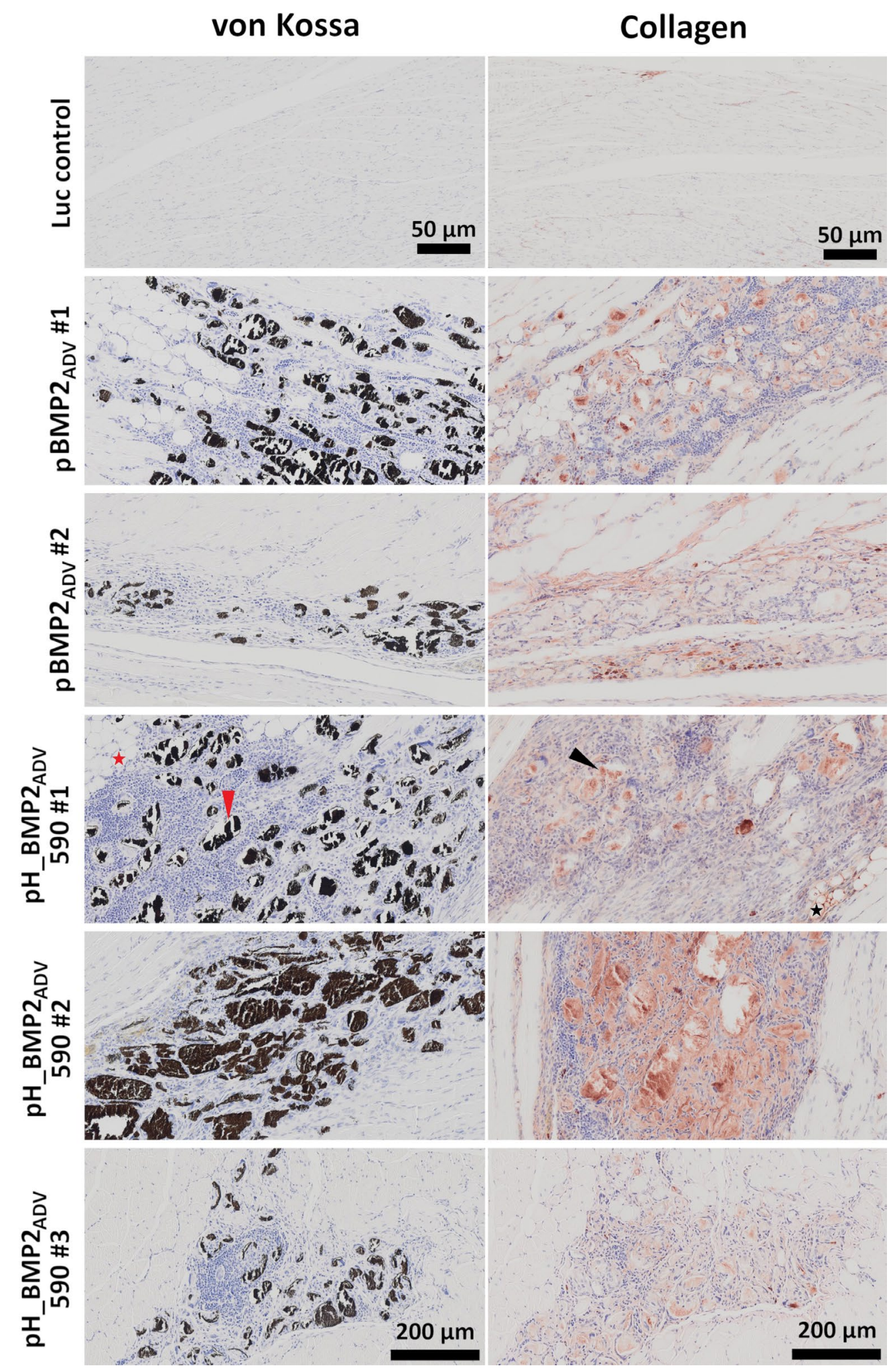

Fig. 13. Histology of intramuscular mineralisation 8 weeks after plasmid transfection. The images are the higher magnification of the area of interest as indicated by the black rectangle in Fig. 12, here stained with von Kossa and antibodies against collagen. The muscle tissue was transfected with luciferase control, pBMP2 ${ }_{\mathrm{ADV}}$ or $\mathrm{pH}$ _BMP2 ${ }_{\mathrm{ADV}} 590$. Mineralised ectopic tissue (arrowhead) is indicated by distinctly black areas visible in the von Kossa staining. Collagen type 2-enriched matrix is indicated by brown staining. Blood vessels (not shown) and fatty tissue (star) are also present within the transformed tissue. To underline variability of induced mineralisation, samples representing high and low response to transfection were included, labelled with \#1 (high response) and \#2 (low response) for the pBMP2 ${ }_{\mathrm{ADV}}$ plasmid. Histological samples $\mathrm{pH} \_\mathrm{BMP} 2$ ADv $590 \# 1$ and $\mathrm{pH} \_\mathrm{BMP} 2$ ADv $590 \# 2$ showed high response, while \#3 represented a low response sample upon transfection. Scale bars at the bottom of images account for all images of column except if indicated differently. 
$A P C$ and consequently activation of $\mathrm{Wnt} / \beta$ catenin signalling (canonical WNT pathway) through stabilisation of Wnt-target gene transcription factor $\beta$ catenin (Wu et al., 2016).

In $\mathrm{C} 2 \mathrm{C} 12$, transfection with $\mathrm{pH} \mathrm{BMP}_{\mathrm{ADV}} \mathrm{scr}$ resulted in increased $\mathrm{Bmp} 2$ protein level detected by ELISA, when compared with $\mathrm{pBMP}{ }_{\mathrm{ADV}}$ (Fig. 3). As the scrambled miRNA does not specifically bind to any known mRNA, this difference must be facilitated by other interactions. Cross-talk between two promoters in local vicinity can lead to a positive, upregulatory effect on neighbouring genes (Hampf and Gossen, 2007). This kind of transcriptional influence has been described for promoters of the same type (polymerase II) (Feichtinger et al., 2014a), where the convergent arrangement of expression cassettes had a favourable effect on transgene expression levels when compared to a divergent arrangement. There might be underlying promoter cross-talk events leading to the observed Bmp2 protein up-regulating properties of the U6-miRNA expression machinery.

Quantification of BMP2 protein secreted by CHO-K1 cells transfected with hybrid constructs showed no significant variance between all tested plasmids (Fig. 4). As this cell line has a reduced consumption of produced BMP2 due to its deficiency in osteogenic differentiation (Garzon-Alvarado et al.et al., 2014), the measured BMP2 protein levels could reflect plasmidal expression more directly. Thus, revealing a consistent expression potential of all tested constructs.

Transcription levels of $B M P 2_{A D V}$ were analysed by RT-qPCR using intron-spanning primers specifically targeting only the codon-optimised version of $B M P 2$. As shown in Fig. 5, mRNA amounts of the introduced therapeutic gene were differing for each hybrid vector as well as between all used cell types $3 \mathrm{~d}$ after transfection. In $\mathrm{CHO}-\mathrm{K} 1$ cells, where protein analysis indicated homogenous expression levels, significant differences in mRNA amounts were detected. In the same cell type, $\mathrm{pBMP} 2_{\mathrm{ADV}}$ and $\mathrm{pH} \mathrm{BMP}_{\mathrm{ADV}} 20 \mathrm{a}$ constructs resulted in the translation of equal Bmp2 protein amount from lower mRNA counts. This phenomenon may be caused by distinct mRNA abundance, ribosome occupancy and turnover (Maier et al., 2009). In C2C12 cells, all miRNA-encoding vectors achieved significantly larger mRNA counts than the conventional $\mathrm{pBMP} 2_{\mathrm{ADV}}$. This finding was consistent with $\mathrm{Bmp} 2$ protein quantification by ELISA (Fig. 3). C3H/10T1/2 cells, on the other hand, only showed significantly enhanced expression of $B M P 2_{A D V}$ mRNA upon transfection with $\mathrm{pH}$ _BMP2 ${ }_{\mathrm{ADV}} 590$, whereas Bmp2 concentrations in supernatants were similarly enhanced by all hybrid vectors. Thus, overexpression of these miRNAs must influence the translation of transgenic and endogenous Bmp2 protein either directly by stabilising the encoding mRNA or indirectly by repressing the translation of inhibiting factors (Vasudevan, 2012).

The next step was to elucidate if miRNAs were de facto overexpressed and if so, to what extent they were secreted into the extracellular environment enabling a paracrine effect that might be involved in the osteoinductive process within the tissue (Linero and Chaparro, 2014; Santos et al., 2011; Scott et al., 2012). This inquiry was confirmed after quantifying miRNA levels of intracellular and extracellular samples following cell transfection (Fig. 6). Hence, upregulation of $\mathrm{miR}-148 \mathrm{~b}-3 \mathrm{p}$ and $\mathrm{miR}-590-5 \mathrm{p}$ inside the cell as well as in the supernatant was detected when cells were transfected with corresponding hybrid vectors, relative to cells transfected with $\mathrm{pBMP} 2_{\mathrm{ADV}}$ construct. Interestingly, miR-148b-3p displayed the highest up-regulation. This might seem favourable, but as a saturation of miRNA-machinery, e.g. exportin-5, can occur, supraphysiological amounts of unprocessed miRNA can be disadvantageous (Grimm et al., 2010). The lower increase in intracellular and extracellular miR-20a-5p, upon hybrid transfection, could be explained by higher endogenous transcript levels in the investigated cell line (data not shown). Thus, the potential relative change is minimised.

miRNAs are reported to regulate many aspects of bone development (Li et al., 2017; Vishal et al., 2017). The present study focused on consequential differentiation of target cells. The evaluation method of choice was RT-qPCR, as it is an acknowledged sensitive transcriptional validation technique and allowed for the study of osteoblast-related genes serving as early and late differentiation markers (Fig. 7). Changes in OCN and Runx2 mRNA after miRNA transfection are reported as early as one night after transfection (Gámez et al., 2013). 3 d after transfection with miR-690, changes in Alpl expression are measured (Yu et al., 2016). Huang et al. (2014) treated $\mathrm{C} 2 \mathrm{C} 12$ with $\mathrm{BMP} 2$ protein for $3 \mathrm{~d}$ leading to changes in OCN and Col1a1 mRNA. Based on these studies, changes in osteogenic gene expression were tested $3 \mathrm{~d}$ after transfection in C2C12 and $6 \mathrm{~d}$ after transfection in $\mathrm{C} 3 \mathrm{H} / 10 \mathrm{~T} 1 / 2$.

In $\mathrm{C} 2 \mathrm{C} 12$, the largest Alpl mRNA fold change occurred upon transfection with pH_BMP2 ${ }_{\mathrm{ADV}} 590$ and $\mathrm{pH}$ _BMP2 2 $20 \mathrm{a}$. Also, the early markers Col1a1 and Runx2 were significantly more up-regulated in the presence of miR-590-5p than upon transfection with $\mathrm{pBMP} 2_{\mathrm{ADV}}$ alone. In $\mathrm{C} 2 \mathrm{C} 12$, mRNA expression levels of OCN were up-regulated the most by pH_BMP2 2 20a transfection. In C3H/10T1/2 cells, pH_BMP2 ${ }_{\mathrm{ADV}} 148 \mathrm{~b}$ and $\mathrm{pH}$ _BMP2 ${ }_{\mathrm{ADV}} 590$ hybrid vectors caused a comparably significant fold change of Alpl mRNA transcription, whereas relative type I collagen mRNA count was similar in all groups, even in the untransfected control. As Alpl is known to be regulated by Wnt3a signalling (Rawadi et al., 2003) in contrast to Col1a1 (Jackson et al., 2005), a differentially regulated signalling pathway may be the explanation for this inconsistent transcriptional regulation upon transfection. Runx2 transcription was not positively affected by miRNA co-expression when compared with $B M P 2_{A D V}$ expression alone. Osteocalcin mRNA quantification indicated an up-regulation in all $\mathrm{C} 3 \mathrm{H} / 10 \mathrm{~T} 1 / 2$ cells transfected with hybrid constructs. 
Generation of NGS profiles after transfection of $\mathrm{C} 3 \mathrm{H} / 10 \mathrm{~T} / 1$ with hybrid plasmids revealed regulation of specific and commonly regulated miRNA targets as depicted in Fig. 8b,c. These findings clearly supported the hypothesis that the plasmid's effects on gene regulation and hence expression are driven by the different miRNAs incorporated in the vectors.

While transfection with $\mathrm{pH}$ _BMP2 ${ }_{\mathrm{ADV}} 590$ resulted in the largest number of significantly up- and downregulated targets, it also showed the largest number of validated miRNA targets extracted from TarBase, which supported its choice for an in vivo study. Of note, miR-590 shares seed sequence homology to miR-21-5p (Web ref. 3), which is also well known for its regulatory role in bone metabolism (Strauss et al., 2020; et al., 2015b; Zarecki et al., 2020).

The presented sum of in vitro gene expression data supported the hypothesis that a combinatorial approach of $B M P 2_{A D V}$ and osteogenic miRNA overexpression led to enhanced osteogenic differentiation. Yet, the inability to proof the own inherent osteogenic potential of the used miRNAs (ALP assay), as well as the absence of transfection experiments in primary MSCs might represent the main limitations of the in vitro study design. Yet, the preliminary in vitro data was considered solid enough to proceed to in vivo testing.

A mouse ectopic-bone model was chosen for translating the hybrid plasmid system from cell culture to an in vivo setting. As the osteoinductive potential of miR-590-5p was most stable in vitro, pH_BMP2 590 hybrid vector was selected for direct comparison with the original $\mathrm{pBMP} 2_{\mathrm{ADV}}$. Each hind limb was transfected with one of the plasmids, allowing for intra-animal comparison. Final highresolution ex vivo $\mu \mathrm{CT}$ scans were conducted after 8 weeks.

In 4 out of 6 hind limbs, transfection with the pH_BMP2 2590 hybrid vector resulted in substantial mineralisation, when compared to the negative control plasmid (Fig. 11). On the other hand, in only 1 out of 6 injected hind limbs, transfection with $\mathrm{pBMP} 2_{\mathrm{ADV}}$ plasmid led to mineralisation. The transfection success-rate of the pH_BMP2 ${ }_{\mathrm{ADV}} 590$ hybrid vector (4 out of 6 limbs, $67 \%$ ) was comparable to the $2 \mathrm{~W}$ sonoporative gene delivery rate of the non-viral BMP2/7 co-expression plasmid constructed by Feichtinger et al. (2014b). Although, sonoporation with $4 \mathrm{~W}$ resulted in a $100 \%$ transfection rate, which is comparable to the viral gene delivery conducted by Luk et al. (2003), who also detected ossification in all rats upon injection of AAV-BMP4. On the other hand, in the present study, the plasmid was administered only once by single injection of DNA-complexes, while sonoporation by Feichtinger et al. (2014b) was carried out repeatedly for 5 consecutive days. However, when compared to Feichtinger's study, the tissue samples of the present study did not show a stem cell niche.

Although both plasmids were able to induce mineralisation in an ectopic model, the hybrid vector showed a higher probability of mineralisation occurrence and, therefore, a greater potential for further in vivo trials. This may be due to a variety of osteoinductive properties of the miR-590-5p, such as increased Alpl expression via targeting Smad7, an inhibitor of osteoblast differentiation (Vishal et al., 2017). Accordingly, hsa-miR-590 overexpression increases pro-osteogenic target expression by stabilisation of $\beta$ catenin in human MSCs (Wu et al., 2016). Confirming previous findings (Chen et al., 2009), extracellular miRNAs was detected in mesenchymal cell supernatants (Fig. 6). Consequently, overexpressed Bmp2 and miR590-5p might act not only intracellularly but also intercellularly via paracrine effects in transfected muscle tissue.

As outlined by Wosczyna et al. (2012), excess BMP and induction of intracellular effectors such as SMADs contribute to ossification within the muscle tissue. In human FOP, a mutation of the $\mathrm{BMP}$ type I receptor (Alk-2) results in hypersensitive or even BMP-independent signalling, leading to ossification of muscle tissue upon soft tissue trauma. Although the detailed pathophysiology of muscle tissue ossification is still unclear, potential explanations for muscle-bone transformation involve recruitment and differentiation of circulating osteoprogenitor cells restricted to the skeletal muscle, such as satellite cells, as well as the contribution of endothelial cells or multipotent mesenchymal cells to the mouse muscle tissue. Concerning bone tissue formation pathways, Lounev et al. (2009) showed that endothelial precursor cells can be triggered by an inflammatory microenvironment to differentiate via the endochondral pathway in an animal model of FOP. Also, a study using adenoviral vectors (Jane et al., 2002) expressing BMP2 for intramuscular injection, showed ectopic-bone formation by endochondral ossification. In the present study, the presence of collagen type II-enriched matrix surrounding mineralised areas (Fig. 12) in the absence of collagen type I (data not shown) suggested bone formation via the endochondral pathway (Stoeger et al., 2002).

The vector system showed great potential for directing the cellular fate toward an osteogenic direction, indicated by mineralisation of transfected muscle tissue. However, a large variation in size and shape of mineralised areas was observed. Therefore, a density threshold (100 - $600 \mathrm{mgHA} / \mathrm{cm}^{3}$ ) was selected to limit areas of mineralisation for volume approximation. Potential diffusion of transfection solution could have led to this widespread effect throughout the layers of soft tissue. To prevent this, biomaterials retaining DNA complexes at the target site could be included in future experiments (Huang et al., 2005; Raftery et al., 2018). Also, a reduction in injection volume might decrease potential effects caused by diffusion.

To increase efficiency and concentration of transfection reagent at the desired region, another 
option for improvement might be repetitive transfections (Kawai et al., 2003). However, regarding ease of handling and application, as well as animalstress reduction, single shot transfection remains the preferable approach, if possible. Finally, since the ectopic-bone model was a first step to prove the efficacy of the plasmids in vivo, experiments in bone defect models will be needed to evaluate their potential for clinical application. Within these models, stationary biomaterials and/or hybrid vector pre-transfected MSCs could locally contribute to stimulate mineralisation and improve bone healing.

The main concept of these plasmids is versatility. The constructs were designed to be adjustable to different target tissues using specific miRNAs with corresponding therapeutic genes, thereby providing the opportunity to meet various clinical demands.

\section{Conclusion}

Scientific findings on miRNAs and their effects have increased in recent years. The present study contributed significantly to the field of tissue regeneration. In vitro validation of double-active non-viral hybrid plasmids showed increased osteoinduction in different cell lines. Acting via simultaneous overexpression of BMP2 and miRNAs, the plasmids not only supported the osteogenic differentiation process, but could also counterbalance the potential drawbacks of conventional gene therapy. Further refinement of invention should be pursued in the future, which could be done in a calvarial defect model. The studied constructs could also be adjusted to meet the requirements for different targets and tissues. Therefore, the presented vector system could meet the demands of a broad field of clinical applications. The present study hoped to encourage additional research on multi-target gene therapeutic approaches.

\section{Availability of data and material}

The datasets used and/or analysed during the current study are available upon reasonable request to the corresponding author.

\section{Acknowledgements}

We thank Matthias Hackl and Andreas Diendorfer (TAmiRNA) for the quantitation and visualisation of miRNA expression profiles, Gabriele Leinfellner for in vivo imaging support and Barbara Schädl, LBIT's competence centre of histology.

T.K.B. built the initial constructs, designed and performed in vitro experiments, analysed data and wrote the manuscript. K.P.M. designed and performed in vivo experiments, histology pre-processing, analysed data and wrote the manuscript. D.H. was involved in drafting and editing of the manuscript. S.S. performed in vitro experiments, analysed data and edited the manuscript. P.H. performed all $\mu \mathrm{CT}$ scans and imaging processing. C.K. performed in vivo experiments and was responsible for animal care. S.N. performed and supervised the histological analysis. H.R. is the director and co-supervisor. A.H. designed and supervised the study. All authors discussed the results and implications and commented on the manuscript at all stages.

The authors declare that they have no competing interests.

\section{References}

Al-Dosari MS, Gao X (2009) Non-viral gene delivery: principle, limitations, and recent progress. AAPS J 11: 671-681.

Anders S, Pyl PT, Huber W (2015) HTSeq-A Python framework to work with high-throughput sequencing data. Bioinformatics 31: 166-169.

Ando H, Hirose M, Kurosawa G, Impey S, Mikoshiba K (2017) Time-lapse imaging of microRNA activity reveals the kinetics of microRNA activation in single living cells. Sci Rep 7: 1-16.

Audigé L, Griffin D, Bhandari M, Kellam J, Rüedi TP (2005) Path analysis of factors for delayed healing and nonunion in 416 operatively treated tibial shaft fractures. Clin Orthop Relat Res 438: 221-232.

Bahr SM, Borgschulte T, Kayser KJ, Lin N (2009) Using microarray technology to select housekeeping genes in Chinese hamster ovary cells. Biotechnol Bioeng 104: 1041-1046.

Bleiziffer O, Eriksson E, Yao F, Horch RE, Kneser U (2007) Gene transfer strategies in tissue engineering. J Cell Mol Med 11: 206-223.

Chen TS, Lai RC, Lee MM, Choo ABH, Lee CN, Lim SK (2009) Mesenchymal stem cell secretes microparticles enriched in pre-microRNAs. Nucleic Acids Res 38: 215-224.

Deng Y, Bi X, Zhou H, You Z, Wang Y, Gu P, Fan $X$ (2014) Repair of critical-sized bone defects with anti-miR-31-expressing bone marrow stromal stem cells and poly(glycerol sebacate) scaffolds. Eur Cells Mater 27: 13-25.

Dimitriou R, Jones E, McGonagle D, Giannoudis PV (2011) Bone regeneration: current concepts and future directions. BMC Med 9: 1-10.

Dobin A, Davis CA, Schlesinger F, Drenkow J, Zaleski C, Jha S, Batut P, Chaisson M, Gingeras TR (2013) STAR: ultrafast universal RNA-seq aligner. Bioinformatics 29: 15-21.

Duvoisin R, Ayuk MA, Rinaldi G, Suttiprapa S, Mann VH, Lee CM, Harris N, Brindley PJ (2012) Human U6 promoter drives stronger shRNA activity than its schistosome orthologue in Schistosoma mansoni and human fibrosarcoma cells. Transgenic Res 21: 511-521.

Ekhteraei-Tousi S, Mohammad-Soltani B, Sadeghizadeh M, Mowla SJ avad, Parsi S, Soleimani 
M (2015) Inhibitory effect of hsa-miR-590-5p on cardiosphere-derived stem cells differentiation through downregulation of TGFB signaling. J Cell Biochem 116: 179-191.

Eliceiri K, Schneider CA, Rasband WS, Eliceiri KW (2012) NIH Image to ImageJ: 25 years of image analysis HISTORICAL commentary NIH Image to ImageJ: 25 years of image analysis. Nat Methods 9: 671-675.

Eskildsen T, Taipaleenmäki H, Stenvang J, Abdallah BM, Ditzel N, Nossent AY, Bak M, Kauppinen S, Kassem M (2011) MicroRNA-138 regulates osteogenic differentiation of human stromal (mesenchymal) stem cells in vivo. Proc Natl Acad Sci USA 108: 6139-6144.

Feichtinger GA, Hacobian A, Hofmann AT, Wassermann K, Zimmermann A, van Griensven M, Redl H (2014a) Constitutive and inducible coexpression systems for non-viral osteoinductive gene therapy. Eur Cell Mater 27: 166-184.

Feichtinger GA, Hofmann AT, Slezak P, Schuetzenberger S, Kaipel M, Schwartz E, Neef A, Nomikou N, Nau T, Van Griensven M, McHale AP, Redl H (2014b) Sonoporation increases therapeutic efficacy of inducible and constitutive BMP2/7 in vivo gene delivery. Hum Gene Ther Methods 25: 57-71.

Gámez B, Rodríguez-Carballo E, Bartrons R, Rosa JL, Ventura F (2013) MicroRNA-322 (miR-322) and its target protein Tob2 modulate osterix (Osx) mRNA stability. J Biol Chem 288: 14264-14275.

Garzon-Alvarado DA, Gutiérrez ML, Calixto LF (2014) A computational model of clavicle bone formation: a mechano-biochemical hypothesis. Bone 61: 132-137.

Glover DJ, Lipps HJ, Jans DA (2005) Towards safe, non-viral therapeutic gene expression in humans. Nat Rev Genet 6: 299-310.

Grimm D, Wang L, Lee JS, Schürmann N, Gu S, Börner K, Storm TA, Kay MA (2010) Argonaute proteins are key determinants of RNAi efficacy, toxicity, and persistence in the adult mouse liver. J Clin Invest 120: 3106-3119.

Hacobian AR, Posa-Markaryan K, Sperger S, Stainer M, Hercher D, Feichtinger GA, Schuh CM, Redl H (2016) Improved osteogenic vector for nonviral gene therapy. Eur Cell Mater 31: 191-204.

Hamberg M, Backes C, Fehlmann T, Hart M, Meder B, Meese E, Keller A (2016) MiRTargetLinkmiRNAs, genes and interaction networks. Int J Mol Sci 17: 1-6.

Hampf M, Gossen M (2007) Promoter crosstalk effects on gene expression. J Mol Biol 365: 911-920.

Huang RL, Yuan Y, Tu J, Zou GM, Li Q (2014) Opposing TNF-/IL-1 $\beta$ - and BMP-2-activated MAPK signaling pathways converge on Runx2 to regulate BMP-2-induced osteoblastic differentiation. Cell Death Dis 5: 1-11.

Huang YC, Simmons C, Kaigler D, Rice KG, Mooney DJ (2005) Bone regeneration in a rat cranial defect with delivery of PEI-condensed plasmid DNA encoding for bone morphogenetic protein-4 (BMP-4). Gene Ther 12: 418-426.
Jackson A, Vayssière B, Garcia T, Newell W, Baron R, Roman-Roman S, Rawadi G (2005) Gene array analysis of Wnt-regulated genes in C3H10T1/2 cells. Bone 36: 585-598.

Jane JA, Dunford BA, Kron A, Pittman DD, Sasaki T, Li JZ, Li H, Alden TD, Dayoub H, Hankins GR, Kallmes DF, Helm GA (2002) Ectopic osteogenesis using adenoviral bone morphogenetic protein (BMP)-4 and BMP-6 gene transfer. Mol Ther 6: 464470 .

Karagkouni D, Paraskevopoulou MD, Chatzopoulos S, Vlachos IS, Tastsoglou S, Kanellos I, Papadimitriou D, Kavakiotis I, Maniou S, Skoufos G, Vergoulis T, Dalamagas T, Hatzigeorgiou AG (2018) DIANA-TarBase v8: a decade-long collection of experimentally supported miRNA-gene interactions. Nucleic Acids Res 46: D239-D245.

Kawai M, Bessho K, Kaihara S, Sonobe J, Oda K, lizuka T, Maruyama H (2003) Ectopic bone formation by human bone morphogenetic protein-2 gene transfer to skeletal muscle using transcutaneous electroporation. HumGene Ther 14: 1547-1556.

Kay MA (2011) State-of-the-art gene-based therapies: the road ahead. Nat Rev Genet 12: 316-328.

Kempen DHR, Creemers LB, Alblas J, Lu L, Verbout AJ, Yaszemski MJ, Dhert WJA (2010) Growth factor interactions in bone regeneration. Tissue Eng Part B Rev 16: 551-566.

Koh JT, Zhao Z, Wang Z, Lewis IS, Krebsbach PH, Franceschi RT (2008) Combinatorial gene therapy with BMP2/7 enhances cranial bone regeneration. J Dent Res 87: 845-849.

Li KC, Lo SC, Sung LY, Liao YH, Chang YH, $\mathrm{Hu}$ YC (2017) Improved calvarial bone repair by hASCs engineered with Cre/loxP-based baculovirus conferring prolonged BMP-2 and MiR-148b coexpression. J Tissue Eng Regen Med 11: 3068-3077.

Liao YH, Chang YH, Sung LY, Li KC, Yeh CL, Yen TC, Hwang SM, Lin KJ, Hu YC (2014) Osteogenic differentiation of adipose-derived stem cells and calvarial defect repair using baculovirus-mediated co-expression of BMP-2 and miR-148b. Biomaterials 35: 4901-4910.

Lian JB, Stein GS, van Wijnen AJ, Stein JL, Hassan MQ, Gaur T, Zhang Y (2012) MicroRNA control of bone formation and homeostasis. Nat Rev Endocrinol 8: 212-227.

Lim LP, Lau NC, Garrett-Engele P, Grimson A, Schelter JM, Castle J, Bartel DP, Linsley PS, Johnson JM (2005) Microarray analysis shows that some microRNAs downregulate large numbers of target mRNAs. Nature 433: 769-773.

Linero I, Chaparro O (2014) Paracrine effect of mesenchymal stem cells derived from human adipose tissue in bone regeneration. PLoS One 9: $1-12$.

Lounev VY, Ramachandran R, Wosczyna MN, Yamamoto M, Maidment ADA, Shore EM, Glaser DL, Goldhamer DJ, Kaplan FS (2009) Identification of progenitor cells that contribute to eterotopic skeletogenesis. J Bone Joint Surg Am 91: 652-663. 
Love MI, Huber W, Anders S (2014) Moderated estimation of fold change and dispersion for RNA-seq data with DESeq2. Genome Biol 15: 1-21.

Luk KDK, Chen Y, Cheung KMC, Kung HF, Lu WW, Leong JCY (2003) Adeno-associated virusmediated bone morphogenetic protein-4 gene therapy for in vivo bone formation. Biochem Biophys Res Commun 308: 636-645.

Maier T, Güell M, Serrano L (2009) Correlation of mRNA and protein in complex biological samples. FEBS Lett 583: 3966-3973.

Masilamani TJ, Loiselle JJ, Sutherland LC (2014) Assessment of reference genes for real-time quantitative PCR gene expression normalization during $\mathrm{C} 2 \mathrm{C} 12$ and $\mathrm{H} 9 \mathrm{c} 2$ skeletal muscle differentiation. Mol Biotechnol 56: 329-339.

Mingozzi F, High KA (2011) Therapeutic in vivo gene transfer for genetic disease using AAV: progress and challenges. Nat Rev Genet 12: 341-355.

Peng B, Chen Y, Leong KW (2015) MicroRNA delivery for regenerative medicine. Adv Drug Deliv Rev 88: 108-122.

Prowse PDH, Elliott CG, Hutter J, Hamilton DW (2013) Inhibition of Rac and ROCK signalling influence osteoblast adhesion, differentiation and mineralization on titanium topographies. PLoS One 8: 17-26.

Qureshi AT, Monroe WT, Dasa V, Gimble JM, Hayes DJ (2013) MiR-148b-nanoparticle conjugates for light mediated osteogenesis of human adipose stromal/stem cells. Biomaterials 34: 7799-7810.

Raftery RM, Mencía-Castaño I, Sperger S, Chen G, Cavanagh B, Feichtinger GA, Redl H, Hacobian A, O'Brien FJ (2018) Delivery of the improved BMP-2-advanced plasmid DNA within a geneactivated scaffold accelerates mesenchymal stem cell osteogenesis and critical size defect repair. J Control Release 283: 20-31.

Rahim MI, Weizbauer A, Evertz F, Hoffmann A, Rohde M, Glasmacher B, Windhagen H, Gross G, Seitz JM, Mueller PP (2017) Differential magnesium implant corrosion coat formation and contribution to bone bonding. J Biomed Mater Res A 105A: 697-709.

Rawadi G, Vayssière B, Dunn F, Baron R, RomanRoman S (2003) BMP-2 controls alkaline phosphatase expression and osteoblast mineralization by a Wnt autocrine loop. J Bone Miner Res 18: 1842-1853.

Santos JL, Pandita D, Rodrigues J, Pêgo AP, Granja PL, Tomás H (2011) Non-viral gene delivery to mesenchymal stem cells: methods, strategies and application in bone tissue engineering and regeneration. Curr Gene Ther 11: 46-57.

Schindelin J, Arganda-Carreras I, Frise E, Kaynig V, Longair M, Pietzsch T, Preibisch S, Rueden C, Saalfeld S, Schmid S, Tinevez J-Y, White DJ, Hartenstein V, Eliceiri K, Tomancak P, Cardona A (2012) Fiji: an open source platform for biological image analysis. Nat Methods 9: 676-682.

Schmittgen TD, Livak KJ (2008) Analyzing realtime PCR data by the comparative CT method. Nat Protoc 3: 1101-1108.
Schoolmeesters A, Eklund T, Leake D, Vermeulen A, Smith Q, Aldred SF, Fedorov Y (2009) Functional profiling reveals critical role for miRNA in differentiation of human mesenchymal stem cells. PLoS One 4: 1-9.

Scott MA, Levi B, Askarinam A, Nguyen A, Rackohn T, Ting K, Soo C, James AW (2012) Brief review of models of ectopic bone formation. Stem Cells Dev 21: 655-667.

Shearwin KE, Callen BP, Egan JB (2005) Transcriptional interference - a crash course. 21: 339-345.

Sood S, Gupta S, Mahendra A (2012) Gene therapy with growth factors for periodontal tissue engineering-a review. Med Oral Patol Oral Cir Bucal 17: e301-310.

Southwood LL, Frisbie DD, Kawcak CE, McIlwraith CW (2004) Delivery of growth factors using gene therapy to enhance bone healing. Vet Surg VS 33: 565-578.

Stoeger T, Proetzel G, Welzel H, Papadimitriou A, Dony C, Balling R, Hofmann C (2002) In situ gene expression analysis during BMP2-induced ectopic bone formation in mice shows simultaneous endochondral and intramembranous ossification. Growth Factors 20: 197-210.

Strauss FJ, Stähli A, Kobatake R, Tangl S, Heimel P, Apaza Alccayhuaman KA, Schosserer M, Hackl M, Grillari J, Gruber R (2020) MiRNA-21 deficiency impairs alveolar socket healing in mice. J Periodontol 91: 1664-167

Umulis D, O'Connor MB, Blair SS (2009) The extracellular regulation of bone morphogenetic protein signaling. Development 136: 3715-3728.

Vasudevan S (2012) Posttranscriptional Upregulation by MicroRNAs. Wiley Interdiscip Rev RNA 3: 311-330.

Vishal M, Vimalraj S, Ajeetha R, Gokulnath M, Keerthana R, He Z, Partridge NC, Selvamurugan N (2017) MicroRNA-590-5p stabilizes Runx2 by targeting Smad7 during osteoblast differentiation. J Cell Physiol 232: 371-380.

Wang W, Li W, Ma N, Steinhoff G (2013) Non-viral gene delivery methods. Curr Pharm Biotechnol 14: 46-60.

Weilner S, Grillari-Voglauer R, Redl H, Grillari J, Nau T (2015a) The role of microRNAs in cellular senes-cence and age-related conditions of cartilage and bone. Acta Orthop 86: 92-99.

Weilner S, Skalicky S, Salzer B, Keider V, Wagner M, Hildner F, Gabriel C, Dovjak P, Pietschmann P, Grillari-Voglauer R, Grillari J, Hackl M (2015b) Differentially circulating miRNAs after recent osteo-porotic fractures can influence osteogenic differentiation. Bone 79: 43-51.

Wilkinson L, Kolle G, Wen D, Piper M, Scott J, Little M (2003) crim1 regulates the rate of processing and delivery of bone morphogenetic proteins to the cell surface. J Biol Chem 278: 34181-34188.

Wosczyna MN, Biswas AA, Cogswell CA, Goldhamer DJ (2012) Multipotent progenitors 
resident in the skeletal muscle interstitium exhibit robust BMP-dependent osteogenic activity and mediate heterotopic ossification. J Bone Miner Res 27: 1004-1017.

Wu S, Liu W, Zhou L (2016) MiR-590-3p regulates osteogenic differentiation of human mesenchymal stem cells by regulating APC gene. Biochem Biophys Res Commun 478: 1582-1587.

Yu S, Geng Q, Pan Q, Liu Z, Ding S, Xiang Q, Sun F, Wang C, Huang Y, Hong A (2016) MiR-690, a Runx2-targeted miRNA, regulates osteogenic differentiation of C2C12 myogenic progenitor cells by targeting NF-kappaB p65. Cell Biosci 6: 1-14.

Zhai Y, Tyagi SC, Tyagi N (2017) Cross-talk of MicroRNA and hydrogen sulfide: a novel therapeutic approach for bone diseases. Biomed Pharmacother 92: 1073-1084.

Zarecki P, Hackl M, Grillari J, Debono M, Eastell R (2020) Serum microRNAs as novel biomarkers for osteoporotic vertebral fractures. Bone 130: 115105. DOI: 10.1016/j.bone.2019.115105.

Zhang J, Fu W, He M, Xie W, Lv Q, Wan G, Li G, Wang H, Lu G, Hu X, Jiang S, Li J, Lin MCM, Zhang Y, Kung H (2011) MiRNA-20a promotes osteogenic differentiation of human mesenchymal stem cells by co-regulating BMP signaling. RNA Biol 8: 829-838.

Zhang Z, Xiang L, Wang Y, Jiang Y, Cheng Y, Xiao GG, Ju D, Chen Y (2020) Effect of Diosgenin on the Circulating MicroRNA Profile of Ovariectomized Rats. Front Pharmacol 11 : 207. DOI: 10.3389/ fphar.2020.00207.

\section{Web References}

1. https://www.bioinformatics.babraham.ac.uk/ projects/fastqc/ [25-09-2020]

2. https://www.ncbi.nlm.nih.gov/geo/info/seq. html [25-09-2020]

3. http://www.targetscan.org/cgi-bin/targetscan/ mmu_71/targetscan.cgi?mirg=mmu-miR-590-5p [2509-2020]

\section{Discussion with Reviewers}

Jennifer Bara: In terms of biological mechanisms, which molecular pathways are known to be involved in BMP2-mediated muscle-bone transformation?

Authors: With regard to molecular signalling pathways leading to formation of ossification in muscle tissue, Kan et al. (2018, additional reference) suggested that aside from the TGF $\beta /$ BMP pathway, other signalling pathways, such as Wnt, the FGF and the Hedgehog pathways, may contribute by cross-talk with the central BMP pathway. Although it is not clear via which specific pathway ectopic mineralisation in the present in vivo study was induced upon transfection with the hybrid plasmid, literature suggests that hsa-miR-590 is involved with TGFBR2 and Smad7 as well as the Wnt/beta catenin signalling pathway and can also induce osteogenic differentiation in MSCs (Ekhteraei-Tousi et al., 2015; Vishal et al., 201, Wu et al., 2016).

Jennifer Bara: What advantages does this vector system confer over other viral and non-viral methods of gene delivery? Could higher levels of control, i.e. an inducible, tissue-specific approach be achieved using this type of hybrid vector?

Authors: One of the general advantages of the vector system was the non-viral base of the plasmid, which allowed for transient expression of therapeutic proteins for tissue regeneration. In contrast to viral gene therapeutic approaches, which holds a multitude of pitfalls, transient therapeutic intervention suits ideally the demands of tissue regeneration. Also, as previous work shows (Hacobian et al., 2016), it is possible to overcome low target-gene expression, one major disadvantage in comparison to viral gene delivery, by combining a strong promotor as well as a codon-optimised BMP2-sequence. Furthermore, by using the combinatorial approach of BMP2 overexpression and miRNA-dependent gene regulation favouring the same result, i.e. pushing cell fate towards osteogenic differentiation and creating a beneficial environment for bone regeneration. Also, as endogenous cells express the introduced BMP2 directly, adequate posttranslational modifications provide more bioactivity in comparison to recombinant proteins (Brooks, 2006; additional reference).

Jennifer Bara: BMP2/BMP7 heterodimers are known to have more osteogenic potency when compared to homodimers. Do the authors know in which form(s) endogenous/plasmid-delivered BMP2 was present? Authors: Immunohistochemistry, using anti-BMP7antibodies, was not performed. Therefore, it is not known if delivered BMP2 was present as a homodimer or as a heterodimer together with endogenous BMP7. However, induction of endogenous BMPs can be achieved upon gene transfer with BMP2 and BMP7 (Zhu et al., 2006, additional reference). Data suggested that most of the released BMP2 was present in a homodimeric state, but additional endogenous expression of other BMPs, including BMP7, probably resulted in different heterodimers. Unfortunately, there is no ELISA assay specified for detecting BMP heterodimers, such as BMP2/BMP7 dimers. The setup was focused on the evaluation of the hybrid vector system using BMP2 homodimers, but with future prospect of integrating co-expression of BMP2 and BMP7 in this system. This could further contribute to successful bone formation, as priorly shown by Feichtinger et al. (2014a) and Kawai et al. (2006) as the heterodimer would be more stable towards endogenous inhibition. 
Georg Feichtinger: The described work tested an expression system designed using human sequences. Are there any differences in target specificity expected in a murine system for the applied miRNAs? Has the target analysis been performed on murine or human transcripts?

Authors: Target prediction has been performed on human transcripts, whereas, high sequence similarities exist for the used miRNAs in both organisms. Both seed sequences of hsa-miR$148 \mathrm{~b}$ are complementary to the murine ortholog mmu-miR-148. Binding sequences for mmu-miR$148 \mathrm{~b}$ are found in the orthologous murine Rock1 mRNA sequence. The murine miR-590, which is complementary to the human miR-590, shares its seed sequence with mmu-miR-21a, which targets the $t g f b 2$, tgfbr1, crim1, bmpr2 and bmpr1a mRNAs. hsa-miR-20a shares binding sites with the murine mmu-miR-20a, these are located in the mRNA sequences of bambi, bmpr2, crim1, bmp2k, bmp2, tgfbr2 and smad 4-7. All data were retrieved from mirbase.org, TarBase and ensembl.org.

Georg Feichtinger: Whilst the current system is interesting and relatively novel, its suitability for clinical translation could be questioned by highlighting the use of highly pleiotrophic miRNAs as effectors, which could affect the expression of multiple known and unknown target transcripts. What obstacles or issues could be faced when planning to use the proposed miRNAs in human patients in the future?

Authors: We agree that miRNA action is pleiotropic, but also that it is considered to fine-regulate and balance homeostasis in cells and tissues. Therefore, the transient transcription of miRNAs in combination with equally pleiotropic proteins such as BMP2 might be therapeutically valuable and, indeed, several RNAi-based therapies are under clinical trials. To bring the approach closer to the clinics, safety has to be tested in pre-clinical models to exclude that the miRNAs might have an influence on a wide range of cell functions, affecting proliferation, differentiation, apoptosis and other metabolic processes by downor up-regulating target-gene expression (Felekkis et al., 2010, additional reference; Lim et al., 2005; Liao et al., 2014; Qureshi et al., 2013; Schoolmeesters et al., 2009; Vishal et al., 2017, additional reference). As opposed to siRNA, complementarity between miRNA and its target mRNA does not require perfect matching. This results in an effect where one mRNA is regulated by a multitude of different miRNAs, while a single miRNA recognises multiple targets at once (Lim et al., 2005), similar to the mechanism of action of transcription factors. Finally, also secretion of miRNAs into the supernatant in the in vitro experiments was observed, implying that systemic effects might be possible. Therefore, it needs to be carefully established whether the increased versatility of the used system, in addition to its higher efficacy, makes it safe to use.
Georg Feichtinger: Inclusion of miRNA cassettes into expression systems might lead to additional positional cis-acting effects that might influence gene expression of the therapeutic transgene positively or negatively and might impact therapeutic outcome indirectly. Did the authors investigate such potential effects using a control cassette or can they comment on this potential effect?

Authors: No, positional cis-acting effects were not investigated. Interestingly, as described in a study by Hampf et al. (2007), in which crosstalk signals between different promotors were investigated, the presence of the EF1 $\alpha$ promotor shows only little effect on reporter gene expression. The possibility of cis-acting effects cannot be excluded. However, the differences in miRNA effects and their impact on gene expression were shown (Fig. 5,7), including NGS data to support the study hypothesis. Therefore, we are convinced that the desired results can not only be due cis-acting contribution by the U6 promotor. As an addition, future experiments may include trials using MetLuc reporter genes to further investigate cis-acting effects.

Georg Feichtinger: miRNA effectors can target specific transcripts or can show a pleiotropic effect due to the regulation of multiple downstream target mRNAs. Did the authors investigate the number of target mRNAs potentially regulated by the employed miRNAs and their function in the obtained NGS data? Can they comment on the potential impact of the targeting of multiple intended and unintended target mRNAs for future translation of this technology?

Authors: NGS was used to investigate commonly regulated targets, pointing out significantly upregulated and down-regulated target genes upon transfection (Fig. 8). Also, significantly downregulated genes were identified by NGS and mapped against all miRNA-specific validated targets derived from TarBase database (Fig. 9).

According to Ishida et al. (2013, additional reference) the full scale of off-target effects is only known when in vivo studies are conducted. Interestingly, it is even suggested that due to the miRNAs modus operandi, this being a simultaneous action of small amplitude on multiple targets, the term off-target is incorrect. However, understanding the targeting of multiple unintended effectors remains a highly complex challenge for future translation into clinical application. As we were able to show on multiple levels of expression that our selected miRNAs had the desired effect, we remain optimistic that our approach will be of high interest in future projects.

\section{Additional References}

Brooks SA (2006) Protein glycosylation in diverse cell systems: implications for modification 
and analysis of recombinant proteins. Expert Rev Proteomics 3: 345-359.

Felekkis K, Touvana E, Stefanou C, Deltas C (2010) MicroRNAs: a newly described class of encoded molecules that play a role in health and disease. Hippokratia 14: 236-240.

Ishida M, Selaru FM (2013) MiRNA-Based Therapeutic Strategies. Curr Pathobiol Rep 1: 63-70.

Kan C, Chen L, Hu Y, Ding N, Lu H, Li Y, Kessler JA, Kan L (2018) Conserved signaling pathways underlying heterotopic ossification. Bone 109: 43-48.

Zhu W, Kim J, Cheng C, Rawlins BA, BoachieAdjei O, Crystal RG, Hidaka C (2006) Noggin regulation of BMP 2/7 heterodimer activity in vitro. Bone 39: 61-71.

Editor's note: The Scientific Editor responsible for this paper was Martin Stoddart.

\section{Supplementary video details \\ (available on paper website)}

Video 1. CT-generated 3D reconstruction of mouse hind limbs 8 weeks after transfection with indicated plasmids. Transfection-induced ectopic mineralisation is shown in colour distinctly located within the soft tissue. Tibial and fibular bone is visible in white. Depicted hind limbs in the video correspond to the samples processed for histology (Fig. 12,13). Samples of high and low response to transfection were included. Upper left hind limb was transfected with luciferase control plasmid. Upper middle (high response) and upper right (low response) hind limbs were transfected with $\mathrm{pBMP}{ }_{\mathrm{ADV}}$ plasmid. Lower left and middle (high response), as well as lower right (low response) hind limbs were transfected with pH_BMP2 ${ }_{\mathrm{ADV}} 590$ plasmid. 